\title{
Modeling of Blast Furnace with Layered Cohesive Zone
}

\begin{abstract}
X.F. DONG, A.B. YU, S.J. CHEW, and P. ZULLI
An ironmaking blast furnace $(\mathrm{BF})$ is a moving bed reactor involving counter-, co-, and crosscurrent flows of gas, powder, liquids, and solids, coupled with heat exchange and chemical reactions. The behavior of multiple phases directly affects the stability and productivity of the furnace. In the present study, a mathematical model is proposed to describe the behavior of fluid flow, heat and mass transfer, as well as chemical reactions in a BF, in which gas, solid, and liquid phases affect each other through interaction forces, and their flows are competing for the space available. Process variables that characterize the internal furnace state, such as reduction degree, reducing gas and burden concentrations, as well as gas and condensed phase temperatures, have been described quantitatively. In particular, different treatments of the cohesive zone (CZ), i.e., layered, isotropic, and anisotropic nonlayered, are discussed, and their influence on simulation results is compared. The results show that predicted fluid flow and thermochemical phenomena within and around the $\mathrm{CZ}$ and in the lower part of the $\mathrm{BF}$ are different for different treatments. The layered $\mathrm{CZ}$ treatment corresponds to the layered charging of burden and naturally can predict the $\mathrm{CZ}$ as a gas distributor and liquid generator.
\end{abstract}

DOI: $10.1007 / \mathrm{s} 11663-009-9327-y$

(C) The Minerals, Metals \& Materials Society and ASM International 2009

\section{INTRODUCTION}

AN ironmaking blast furnace $(\mathrm{BF})$ is a multiphase reactor involving counter-, co- and/or, cross-current flows of gas, powder, liquid, and solid phases. ${ }^{[1]}$ In this process, iron-bearing materials and coke are charged at the top of the furnace. Hot gas (blast) enters the furnace through the tuyeres in the lower part and combusts carbonaceous materials (coal, coke) to form reducing gas. As this gas ascends, it reduces and melts the ironbearing materials to form liquid iron and slag in the cohesive zone (CZ). The liquid percolates through the coke bed to the hearth. If pulverized coal injection or other injection technology is practiced, then unburnt coal (or other injectants) may leave the raceway region at high injection rates through gas entrainment as a distinct powder phase. ${ }^{[2]}$ These characteristics demonstrate the complexity of the $\mathrm{BF}$ operation and the difficulties in understanding the physical and chemical phenomena in a BF.

Since the 1960s, intensive research has been undertaken to characterize the internal state of a BF with different techniques such as dissection studies, in situ measurements, physical experimentation, and mathematical modeling. Among them, numerical modeling demonstrates an increasing capability to provide detailed information about fluid flow, heat and mass

X. F. DONG, Research Associate, and A. B. YU, Federation Fellow and Scientia Professor, are with the Lab for Simulation and Modelling of Particulate Systems, School of Materials Science and Engineering, University of New South Wales, Sydney, NSW 2052, Australia, Contact e-mail: a.yu@unsw.edu.au S. J. CHEW, Principal Research Engineer, and P. ZULLI, Senior Principal Research Engineer, are with BlueScope Steel Research, P.O. Box 202, Port Kembla, NSW 2505, Australia.

Manuscript submitted February 17, 2009.

Article published online January 5, 2010. transfer, as well as chemical reactions throughout the furnace. One-, two-, and three-dimensional continuumbased mathematical models have been developed in sequence, as summarized in recent reviews. ${ }^{[3-5]}$ The development of numerical models originated from the understanding of macroscopic phenomena at the early stage toward the simulation of critical operational conditions and flow phenomena on a microscale. Corresponding to this trend, the $\mathrm{CZ}$ has attracted much attention in recent years. Through dissection studies, the existence of the $\mathrm{CZ}$ as a layered structure where burden materials undergo dramatic physiochemical change has been demonstrated. Within the $\mathrm{CZ}$, the iron-bearing materials experience softening and melting and react with the reducing gases to produce wustite and iron. Therefore, this zone comprises alternate layers of coke and semifused masses of slag and iron. Through this zone, the layered structure of solid ore and coke in the upper part of the BF gradually transits to the lower zone where only the solid coke remains alongside gases and liquids. The resistance to upward gas flow is great in the $\mathrm{CZ}$ because the ore layers are relatively impermeable, which results in most of the gas traveling through the intermediate coke layers. The shape and position of the $\mathrm{CZ}$ can change significantly with operational conditions $^{[1,6]}$ and, because of its restricted permeability and role as a gas and liquid distributor, largely determines the BF performance and operational stability. To understand this zone, several numerical and physical experiments have been conducted to study the hightemperature properties of iron-bearing materials, ${ }^{[7-14]}$ reaction mechanisms, ${ }^{[15]}$ fluid flow behavior, and temperature distributions ${ }^{[6,16-20]}$ within the CZ. These studies highlight the complex softening-melting behavior, which include the variation of permeability and strong horizontal gas and liquid flows in the CZ. Moreover, efforts have been made to establish the 
relationship among permeability, fluid flow, and heat transfer in this zone, ${ }^{[21-23]}$ which resulted in the development of several empirical and semiempirical $\mathrm{CZ}$ models. Among them, the so-called ZAP model ${ }^{[24]}$ shows the capability to predict the shape and position of the $\mathrm{CZ}$ partially based on online measured data and on summarized relationships between process parameters and $\mathrm{CZ}$ characteristics.

Apart from the intensive fundamental studies discussed, the prediction of the $\mathrm{CZ}$ in global $\mathrm{BF}$ modeling has proven a long-standing challenging task. Different numerical treatments have been used to simulate the $\mathrm{CZ}$ structure in BF modeling, which generally can be summarized as nonlayered and layered $\mathrm{CZ}$ treatments. For a nonlayered $\mathrm{CZ}$ treatment, the $\mathrm{CZ}$ is treated as a mixed region of iron-bearing materials and coke where isotropic or anisotropic permeability distributions can be applied in steady or unsteady simulation. ${ }^{[1]}$ For a layered $\mathrm{CZ}$ treatment, the $\mathrm{CZ}$ is numerically modeled as a region comprising impermeable or low-permeability iron-bearing material layers and highly permeable coke layers. ${ }^{[25-30]}$ The existence of this layered structure makes modeling more difficult. For example, to treat liquid flow in the layered $\mathrm{CZ}$, the so-called force balance mode ${ }^{[18,31,32]}$ had to be modified to allow the liquid to traverse the impermeable cohesive layers. Nonlayered CZ treatments simplify the modeling and can facilitate early application and development. However, ignoring the existence of alternate layers of impermeable ironbearing materials and permeable coke windows can make it difficult for a nonlayered $\mathrm{CZ}$ treatment to reproduce the fluid flow, temperature, and concentration fields realistically within and around the CZ. Moreover, this treatment often induces a potentially artificial level of permeability in the $\mathrm{CZ}$ to yield a solution to the gas flow field. In contrast, a layered CZ treatment explicitly considers the stratified structure of iron-bearing materials and coke, which is consistent with a realistic $\mathrm{CZ}$ structure. Unfortunately, one major shortcoming associated with most past studies that used a layered $\mathrm{CZ}$ treatment is that the $\mathrm{CZ}$ shape and position were specified in advance and may have been inconsistent with other operational parameters. Although the recent MOGADOR model ${ }^{[24,33]}$ has captured the overall $\mathrm{CZ}$ position considering the layered burden distribution in the simulation, a relatively high permeability is maintained in the simulated fused ore layer of the $C Z,{ }^{[33]}$ which indicates that the layered structure in the $\mathrm{CZ}$ is still considered implicitly.

To better demonstrate the effect of impermeable fused ore layers in the $\mathrm{CZ}$ on the process variables, this study attempts to establish a BF modeling system considering the fluid flow, heat transfer, and chemical reactions to predict the layered $\mathrm{CZ}$ explicitly. The characteristics of the flow and thermochemical behavior in a BF will be demonstrated through a comparison of process modeling with different $\mathrm{CZ}$ treatments.

\section{NUMERICAL MODELING}

In this section, the governing equations used in the simulation are described first. The relevant model parameters then are discussed in detail, and the numerical treatments of the $\mathrm{CZ}$, i.e., layered and nonlayered, are described. Finally, numerical techniques in regard to the discretization approach, solution algorithm, and multiphysics field coupling are described.

\section{A. Governing Equations}

Table I summarizes the governing equations for fluid flow, heat and mass transfer, as well as chemical reactions used in this work. Gas was described by the well-established volume-averaged, multiphase, NavierStokes equations. ${ }^{[2,5]}$ Solids were assumed to be a

Table I. Governing Equations

\begin{tabular}{|c|c|}
\hline Equations & Description \\
\hline Mass conservation & $\nabla \cdot\left(\varepsilon_{\mathrm{i}} \rho_{\mathrm{i}} \mathbf{u}_{\mathrm{i}}\right)=S_{\mathrm{i}}$, where $S_{\mathrm{i}}=-\sum \beta_{\mathrm{i}, \mathrm{k}} R_{\mathrm{k}}^{*}$ \\
\hline \multirow{3}{*}{$\begin{array}{l}\text { Momentum conservation } \\
\text { Gas }\end{array}$} & 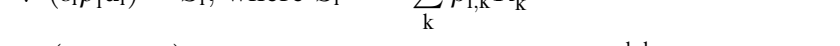 \\
\hline & $\nabla \cdot\left(\varepsilon_{\mathrm{g}} \rho_{\mathrm{g}} \mathbf{u}_{\mathrm{g}} \mathbf{u}_{\mathrm{g}}\right)=\nabla \cdot \tau_{\mathrm{g}}-\varepsilon_{\mathrm{g}} \nabla p+\rho_{\mathrm{g}} \varepsilon_{\mathrm{g}} \mathbf{g}+\mathbf{F}_{\mathrm{g}}^{\mathrm{s}}+\mathbf{F}_{\mathrm{g}}^{\mathrm{l}, \mathrm{d}}$ \\
\hline & $\tau_{\mathrm{g}}=\varepsilon_{\mathrm{g}} \mu_{\mathrm{g}}\left[\nabla \mathbf{u}_{\mathrm{g}}+\left(\nabla \mathbf{u}_{\mathrm{g}}\right)^{\mathrm{T}}\right]-\frac{2}{3} \varepsilon_{\mathrm{g}} \mu_{\mathrm{g}}\left(\nabla \cdot \mathbf{u}_{\mathrm{g}}\right) \mathrm{I}$ \\
\hline \multirow[t]{2}{*}{ Solid } & $\nabla \cdot\left(\varepsilon_{\mathrm{s}} \rho_{\mathrm{s}} \mathbf{u}_{\mathrm{s}} \mathbf{u}_{\mathrm{s}}\right)=\nabla \cdot \tau_{\mathrm{s}}-\varepsilon_{\mathrm{s}} \nabla p_{\mathrm{s}}+\rho_{\mathrm{s}} \varepsilon_{\mathrm{s}} \mathbf{g}$ \\
\hline & $\tau_{\mathrm{s}}=\varepsilon_{\mathrm{s}} \mu_{\mathrm{s}}\left[\nabla \mathbf{u}_{\mathrm{s}}+\left(\nabla \mathbf{u}_{\mathrm{s}}\right)^{\mathrm{T}}\right]-\frac{2}{3} \varepsilon_{\mathrm{s}} \mu_{\mathrm{s}}\left(\nabla \cdot \mathbf{u}_{\mathrm{s}}\right) \mathrm{I}$ \\
\hline Liquid & $\mathbf{F}_{1, \mathrm{~d}}^{\mathrm{g}}+\mathbf{F}_{1, \mathrm{~d}}^{\mathrm{s}}+\varepsilon_{1, \mathrm{~d}} \rho_{1} \mathbf{g}=0$ \\
\hline \multirow[t]{4}{*}{ Heat and species conservation } & $\nabla \cdot\left(\varepsilon_{\mathrm{i}} \rho_{\mathrm{i}} \mathbf{u}_{\mathrm{i}} \phi_{\mathrm{i}, \mathrm{m}}\right)-\nabla \cdot\left(\varepsilon_{\mathrm{i}} \Gamma_{\mathrm{i}} \nabla \phi_{\mathrm{i}, \mathrm{m}}\right)=S_{\phi_{\mathrm{i}, \mathrm{m}}}$ \\
\hline & if $\phi_{\mathrm{i}, \mathrm{m}}$ is $H_{\mathrm{i}, \mathrm{m}}, \Gamma_{\mathrm{i}}=\frac{k_{\mathrm{i}}}{c_{\mathrm{p}, \mathrm{i}}}$ \\
\hline & $S_{\phi_{\mathrm{i}, \mathrm{m}}}=\delta_{\mathrm{i}} h_{\mathrm{ij}} \alpha\left(T_{\mathrm{i}}-T_{\mathrm{j}}\right)+c_{\mathrm{p}, \mathrm{i}} T_{\mathrm{i}} \delta_{\mathrm{i}} \sum_{\mathrm{k}} \sum_{1} \beta_{\mathrm{k}, 1} R_{\mathrm{k}}^{*}+\eta_{\mathrm{i}} \sum_{\mathrm{k}} R_{\mathrm{k}}^{*}\left(-\Delta H_{\mathrm{k}}\right)$ \\
\hline & if $\phi_{\mathrm{i}, \mathrm{m}}$ is $\omega_{\mathrm{i}, \mathrm{m}}, \Gamma_{\mathrm{i}}=\rho_{\mathrm{i}} D_{\mathrm{i}}, S_{\phi_{\mathrm{i}, \mathrm{m}}}=\sum_{\mathrm{k}} \alpha_{\mathrm{i}, \mathrm{m}, \mathrm{k}} R_{\mathrm{k}}^{*}$, where \\
\hline Phase volume fraction & $\begin{array}{l}\phi_{\mathrm{i}, \mathrm{m}}=\omega_{\mathrm{g}, \mathrm{co}}, \omega_{\mathrm{g}, \mathrm{co}_{2}}, \omega_{\mathrm{s}, \mathrm{Fe}_{2} \mathrm{O}_{3}}, \omega_{\mathrm{s}, \mathrm{Fe}_{3} \mathrm{O}_{4}}, \omega_{\mathrm{s}, \mathrm{FeO}}, \omega_{\mathrm{s}, \mathrm{flux}} \\
\sum_{\mathrm{i}} \varepsilon_{\mathrm{i}}=1\end{array}$ \\
\hline State equation & $p=\sum_{\mathrm{i}}\left(y_{\mathrm{i}} M_{i}\right) R T_{\mathrm{g}} / V_{\mathrm{g}}$ \\
\hline
\end{tabular}


continuous phase that can be modeled based on the typical viscous model used in multiphase flow modeling. ${ }^{[34]}$ Liquids flow as rivulets or droplets under the influence of gravity, gas drag, and bed resistance, which can be described by the so-called force balance approach. ${ }^{[18,35]}$ General convection-diffusion equations were applied to describe heat and mass transfer among the phases.

\section{B. Momentum Transfer, Chemical Reactions, and Transport Coefficients}

The following correlation:

$$
\mathbf{F}_{\mathrm{g}}^{\mathrm{s}}=-\left(\alpha_{\mathrm{f}} \rho_{\mathrm{g}}\left|\mathbf{u}_{\mathrm{g}}^{\mathrm{s}}\right|+\beta_{\mathrm{f}}\right) \mathbf{u}_{\mathrm{g}}^{\mathrm{s}}
$$

is an Ergun-type equation ${ }^{[5]}$ that is used to describe the interaction force between gas and solid phases. Interaction forces between gas and liquid $\mathbf{F}_{\mathrm{g}}^{\mathrm{l}, \mathrm{d}}$ as well as between solid and liquid $\mathbf{F}_{\mathrm{s}}^{1, \mathrm{~d}}$ were described by the recent correlations of Chew et al. ${ }^{[35]}$ These correlations are summarized in Table II. As is shown in Table III, chemical reactions are taken into account, which include direct and indirect reduction of iron ore by coke and
$\mathrm{CO},{ }^{[36]}$ solution loss, ${ }^{[37]}$ and melting of Fe and FeO. ${ }^{[38,39]}$ Because the verification of chemical reactions is beyond this study, reaction rates applied in other BF modeling were adopted. Furthermore, because the hydrogen proportion in the current simulation system was small, hydrogen reduction and gas-water reactions were not considered. The transport coefficients that determine heat and mass transfer within and between phases were estimated and described in the following sections.

\section{Effective Diffusion Coefficients}

The effective gas diffusion coefficient was determined by the relationship between the Peclet Number and the Reynolds number. ${ }^{[1]}$ Diffusion coefficients for solid and liquid phases were ignored.

\section{Effective Conductivity Coefficients}

Gas conductivity ${ }^{[1]}$ was determined by the following equation:

$$
k_{\mathrm{gn}}=c_{\mathrm{p}} \rho D_{\mathrm{gn}}^{\mathrm{e}}
$$

The effective solid conductivity coefficient was determined by the effective heat conductivity caused by contact between particles and by radiation between

\begin{tabular}{|c|c|c|}
\hline Phases & Interaction Forces & Ref. \\
\hline Gas-solid, G-S & $\mathbf{F}_{\mathrm{g}}^{\mathrm{s}}=-\mathbf{F}_{\mathrm{s}}^{\mathrm{g}}=-\left(\alpha_{\mathrm{f}} \rho_{\mathrm{g}}\left|\mathbf{u}_{\mathrm{g}}^{\mathrm{s}}\right|+\beta_{\mathrm{f}}\right) \mathbf{u}_{\mathrm{g}}^{\mathrm{s}}$ & [5] \\
\hline Gas-liquid, G-L & $\begin{array}{l}\mathbf{F}_{\mathrm{g}}^{\mathrm{l}, \mathrm{d}}=-\mathbf{F}_{1, \mathrm{~d}}^{\mathrm{g}}=-\left(\frac{h_{1, \mathrm{~d}}}{d_{\mathrm{l}}}+\frac{A_{\mathrm{sl}, \mathrm{d}}}{6}\right)\left[150\left(\frac{\varepsilon_{\mathrm{s}}+h_{1, \mathrm{t}}}{d_{\mathrm{w}}}\right) \mu_{\mathrm{g}}+1.75 \rho_{\mathrm{g}}\left|\mathbf{U}_{\mathrm{g}}\right|\right] \frac{\mathbf{U}_{\mathrm{g}}}{\varepsilon_{\mathrm{g}}^{3}} \text { where } \\
d_{1}=\max \left\{d_{\mathrm{l}, \mathrm{g}}, d_{1, \mathrm{~h}}\right\} \\
d_{1, \mathrm{~g}}=\left[\max \left\{-6.828 \operatorname{sign}\left(\sqrt{X_{\mathrm{p}}}-0.891\right)\left(\sqrt{X_{\mathrm{p}}}-0.891\right)^{2}, 0\right\}+0.695\right] / \sqrt{\rho_{\mathrm{l}} g / \sigma} \\
d_{1, \mathrm{~h}}=\frac{\left[\max \left\{6.828 \operatorname{sign}\left(f_{\mathrm{f}}\right)\left(f_{1}\right)^{2}, 0\right\}+0.695\right]}{\sqrt{\rho_{\mathrm{l}} g / \sigma}} \\
f_{1}=\left[\max \frac{\left\{\ln \left(\frac{h_{1, \mathrm{t}}}{h_{1, \mathrm{t}}}\right), 0\right\}}{0.513}\right]^{\frac{1}{2.642}}-0.891 \\
X_{\mathrm{p}}=\frac{\Delta p_{\mathrm{e}}}{\left(\Delta x \rho_{\mathrm{g}} g\right)}\left\{\rho_{1} g \varphi^{2} \frac{d_{\mathrm{s}}^{2}}{\frac{\sigma}{\varepsilon_{\mathrm{s}}^{2}}}\right\}^{0.3}(1+\cos \theta)^{-0.5}\end{array}$ & {$[35]$} \\
\hline Liquid-solid, L-S & $\mathbf{F}_{1, \mathrm{~d}}^{\mathrm{s}}=\left(\frac{150}{36} \mu_{1} \frac{A_{\mathrm{sl}, \mathrm{d}}^{2}}{h_{1, \mathrm{~d}}^{3}}+\frac{1.75}{6} \rho_{1} \frac{A_{\mathrm{s}, \mathrm{d}}}{h_{1, \mathrm{~d}}^{3}}\left|\mathbf{U}_{l}\right|\right) \mathbf{U}_{l}$ & {$[35]$} \\
\hline
\end{tabular}

Table II. Empirical Correlations for the Interaction Forces Between Phases

\begin{tabular}{|c|c|c|}
\hline Reaction Formula & Reaction Rate & Reference \\
\hline $\mathrm{Fe}_{2} \mathrm{O}_{3(\mathrm{~s})}+\mathrm{CO}_{(\mathrm{g})} \rightarrow \mathrm{Fe}_{(\mathrm{s})}+\mathrm{CO}_{2(\mathrm{~g})}$ & $R_{1}^{*}=\frac{12 \xi_{\mathrm{ore}} \varepsilon_{\mathrm{ore}} P\left(y_{\mathrm{co}}-y_{\mathrm{co}}^{*}\right) /\left(8.314 T_{\mathrm{s}}\right)}{d_{\mathrm{ore}}^{2} / D_{\mathrm{g}, \mathrm{co}}^{\mathrm{e}}\left[\left(1-f_{\mathrm{o}}\right)^{-\frac{1}{3}}-1\right]+d_{\mathrm{ore}}\left\{k_{1}\left(1+\left(1 / K_{1}\right)\right)\right\}^{-1}}$ & [36] \\
\hline $\mathrm{FeO}_{(\mathrm{l})}+\mathrm{C}_{(\mathrm{s})} \rightarrow \mathrm{Fe}_{(\mathrm{l})}+\mathrm{CO}_{(\mathrm{g})}$ & $R_{2}^{*}=\frac{k_{2} A_{\mathrm{c}}}{\mathrm{V}_{\mathrm{b}} a_{\mathrm{FeO}}}$ & {$[1]$} \\
\hline $\mathrm{C}_{(\mathrm{s})}+\mathrm{CO}_{2(\mathrm{~g})} \rightarrow 2 \mathrm{CO}_{(\mathrm{g})}$ & $R_{3}^{*}=\frac{6 \xi_{\text {coke }} \varepsilon_{\text {coke }} p y_{\mathrm{co}_{2}} /\left(8.314 T_{\mathrm{s}}\right)}{d_{\text {coke }} / k_{\mathrm{f}}+6 /\left(\rho_{\text {coke }} E_{\mathrm{f}} k_{3}\right)}$ & [1] \\
\hline $\begin{array}{l}\mathrm{FeO}_{(\mathrm{s})} \rightarrow \mathrm{FeO}_{(1)} \\
\operatorname{Flux}_{(\mathrm{s})} \rightarrow \operatorname{slag}_{(1)}\end{array}$ & $R_{4}^{*}=\left\langle\frac{T_{\mathrm{i}}-T_{\min , \mathrm{sm}}}{T_{\mathrm{max}, \mathrm{sm}}-T_{\min , \mathrm{sm}}}\right\rangle_{0}^{1} \frac{\oint \omega_{\mathrm{sm}} \mathbf{u}_{\mathrm{i}} \rho_{\mathrm{i}} \varepsilon_{\mathrm{i}} d A}{M_{\mathrm{sm}} \mathrm{Vol}_{\text {cell }}}$ & [38] \\
\hline
\end{tabular}

Table III. Chemical Reactions 
noncontacting particles. ${ }^{[1]}$ The corresponding estimation equation is expressed as follows:

$$
k_{\mathrm{se}}^{\mathrm{e}}=\frac{\left(1-\varepsilon_{\mathrm{g}}\right)}{\left(\frac{1}{k_{\mathrm{s}}}+\frac{1}{k_{\mathrm{s}}^{\mathrm{e}}}\right)+\varepsilon_{\mathrm{g}} k_{\mathrm{s}}^{\mathrm{e}}}
$$

where $k_{\mathrm{s}}^{\mathrm{e}}=2.29 \times 10^{-7} d_{\mathrm{s}} T_{\mathrm{s}}^{3}$. Effective thermal conductivities of liquid slag and hot metal were determined according to the literature data. ${ }^{[38]}$

\section{Heat Transfer Coefficients Between Phases}

The heat transfer coefficient between gas and solid particles was described by the Ranz-Marshall correlation,

$$
\mathrm{Nu}=2.0+0.6(\operatorname{Pr})^{0.333}\left(9 \mathrm{Re}_{\mathrm{g}}\right)^{0.5}
$$

where $h_{\mathrm{gs}}=\gamma h_{\mathrm{gs}}^{\mathrm{e}}, h_{\mathrm{gs}}^{\mathrm{e}}=\mathrm{Nu}_{\frac{\mathrm{g}}{d_{\mathrm{s}}}}$, and $\gamma=0.3$. As the permeability of the softening phase is lost within the $\mathrm{CZ}$, heat transfer from the gas phase gradually changes from a gas-particle heating mode to a gas-slab heating mode. ${ }^{[40,41]}$ The heat transfer coefficient between gas and the interface of softening and melting phase was assumed to be expressed as follows:

$$
h_{\mathrm{g} \text {-slab }}=\left(0.203 \operatorname{Re}_{\mathrm{g}}^{0.33} \operatorname{Pr}^{0.33}+0.220 \operatorname{Re}_{\mathrm{g}}^{0.8} \operatorname{Pr}^{0.4}\right) k_{\mathrm{g}} / d_{\mathrm{s}}
$$

The heat transfer coefficients between gas and liquid and between solid and liquid are available elsewhere. ${ }^{[1,34]}$

\section{Heat Loss Through the Furnace Wall}

For the wall boundary condition, heat transfer could be expressed using Newton's Law of Cooling. The temperature gradient normal to the furnace wallcalculated using the wall thickness and temperatures at the inner and outer surfaces-determined heat loss through the wall. Based on the assumed thickness and refractory materials, the heat conduction coefficient in the furnace wall was expressed as $5 \mathrm{~W} \times \mathrm{m}^{-1} \times \mathrm{K}^{-1}$.

\section{CZ Treatments}

The softening and melting zone within the BF, i.e., the so-called $\mathrm{CZ}$, contributed significantly to the process complexity. This zone was of critical importance for efficient operation of the BF and because its shape and position determined the permeability, fluid flow, gas use, thermal and chemical efficiency, and hot-metal quality in the furnace. Within this region, iron-bearing materials were gradually transformed from the lumpy, to the softening, to the half-molten states before finally melting down. Instead of passing through the low permeability portion of this region, the reducing gas can flow radially through adjacent coke layers, which formed a lowresistance path between dripping and lumpy zones. This finding implies a possible retardation of heating and reduction rates for iron-bearing materials in the $\mathrm{CZ}$, with direct gas contact only occurring at the iron-bearing materials-coke interface. Therefore, careful consideration must be given to the internal structure of the CZ.
Physically, the CZ may be subdivided into the following different states as shown in Figure $1(\mathrm{a})^{[42]}$ : molten, softening, lumpy, and coke-only. According to the analysis of Kanbara et al., ${ }^{[43]}$ in Figure 1(a), distributions of metallic iron and slag were present, whereas in Figure 1(b), iron-bearing materials were about $70 \mathrm{pct}$ reduced and bonded together. Their bonding was made possible by the metallic iron produced on the surfaces of ores or by the slag transuding from their inside; in part C, iron-bearing materials existed in a lumpy state without softening and agglomerating. With reference to the work done by Gudenau et al. ${ }^{[22,23]}$ and Bakker et al., ${ }^{[44]}$

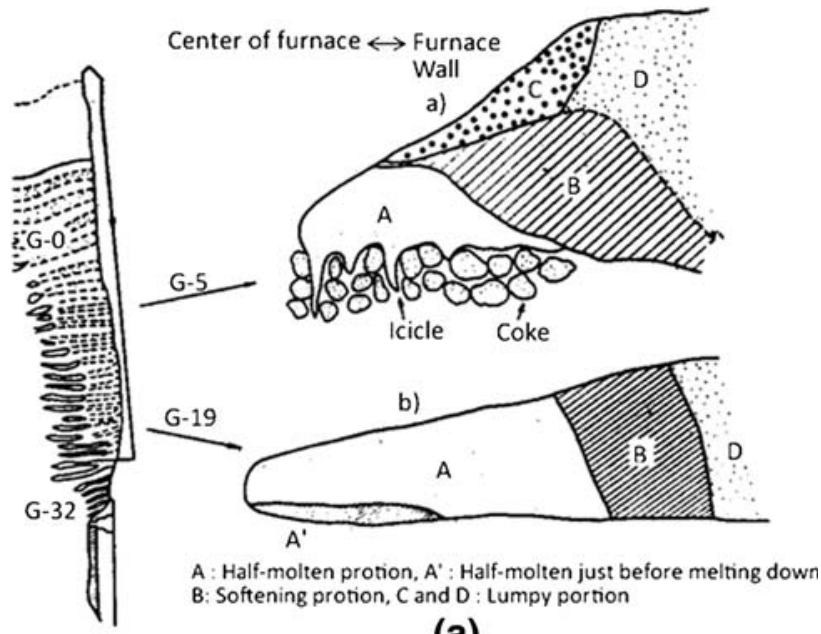

(a)
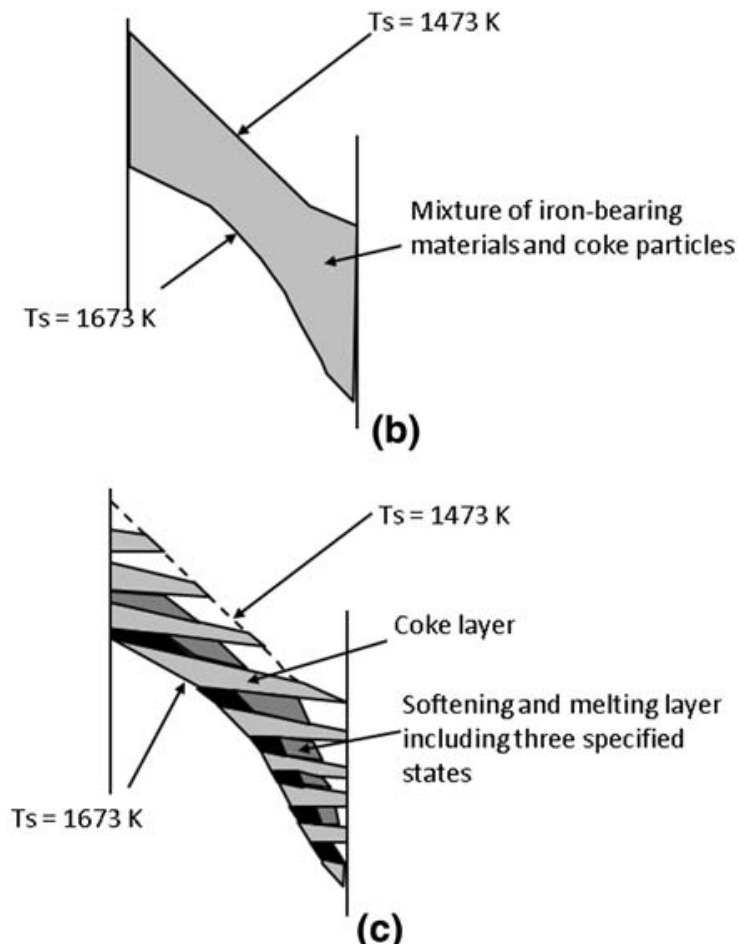

Fig. 1-Schematic shows the $(a)$ internal state of the cohesive zone $^{[42]}$; $(b)$ temperature-based definition of the nonlayered cohesive zone; and $(c)$ defined layered cohesive zone. Note that $T_{\mathrm{s}}$ refers to solid phase temperature even for the solid which is in the melting state. 
corresponding to the complex structure of the $\mathrm{CZ}$, the permeability variation exhibited the following characteristics: at the early stage of softening and melting, although the iron-bearing materials experienced a significant deformation, the macroporosity of the bed remained open and a pressure drop did not significantly increase; as softening and melting continued, once the FeO-containing melt was exuded from the individual bed components into the macroporosity of the bed, a marked increase occurred in the pressure drop over the bed; at the final stage, the melt started to drip from the molten portion so that much of the region was occupied by the liquid phase, and the gas only could flow through to the lumpy zone through the coke windows.

The numerical treatment of a $\mathrm{CZ}$ exerted a strong influence in BF modeling. Therefore, in the current simulation, three CZ treatments were used and compared with each other, i.e., isotropic and anisotropic nonlayered treatments, and a layered treatment, as shown in Figures 1(b) and (c). For the first two treatments, which represent the traditional modeling approach, ${ }^{[1]}$ the $\mathrm{CZ}$ was treated as a mixed region of iron-bearing materials and coke particles. For the third treatment, the $\mathrm{CZ}$ was treated as a layered structure. To model the structure of Figure 1(a) according to BF dissection studies, the stratified structure of coke and iron-bearing material (ore) layers was first calculated based on the solid flow field; then, the $\mathrm{CZ}$ was defined to start and finish within the temperature range 1473$1673 \mathrm{~K}$. Finally, the $\mathrm{CZ}$ region was divided into alternate coke as well as softening and melting layers. In $\mathrm{BF}$ practice, the state of the softening and melting layer was dependent on the high temperature properties of iron-bearing materials and the specific operating conditions. However, for simplicity, in the current study the CZ state was based on previous fundamental studies. With reference to the work done by Gudenau et al. ${ }^{[22,23]}$ and Bakker et al., ${ }^{[44]}$ the following three states were specified: (1) state I, $0.7<S h_{\mathrm{r}}^{*}<1.0$ corresponded to the portion with molten state and liquid source in which the ore layer voidage was occupied fully by the liquid phase; (2) state II, $0.5<S h_{\mathrm{r}}^{*} \leq 0.7$ corresponded to the combined portion with softening and melting of ironbearing materials in which the pressure drop may have increased significantly; (3) state III, $0.0<S h_{\mathrm{r}}^{*} \leq 0.5$ corresponded to the softening stage in which the macropores of the bed remained open so the variation of the pressure drop was limited. Solid conduction and the gas-solid heat transfer coefficient should be specified according to the different heat and mass transfer mechanisms in each of the states. Note that property variations for iron-bearing materials in the $\mathrm{CZ}$ corresponding to these states also were considered in nonlayered treatments.

The detailed comparisons for these three treatments are summarized in Table IV, which shows the differences in dealing with solid volume fraction, particle size, solid heat conductivity, and gas resistance in the CZ. These differences may affect gas and liquid flow modeling significantly, although the solid phase had to maintain some mixed properties of iron-bearing materials and coke in the $\mathrm{CZ}$ to guarantee the overall heat and mass conservation. These different $\mathrm{CZ}$ treatments were applied separately in the simulation with the same boundary conditions and the same numerical techniques described in the following section.

\section{Numerical Technique}

A proprietary code was developed to solve the conservation equations based on the finite volume method, which is also the basis of most commercial CFD codes such as Fluent, ${ }^{[45]} \mathrm{CFX}^{[46]}$ and Star-CD ${ }^{[47]}$ in use today. The solution domain was subdivided into computational cells (control volumes) using a structured and collocated grid where all variables were defined in the center of a cell. ${ }^{[48]}$ To avoid checkerboard pressurevelocity decoupling, Rhie-Chow interpolation was applied, ${ }^{[49]}$ which uses a momentum-based interpolation for the cell face mass fluxes in the continuity equation that closely imitates the staggered practice by forcing mass conservation to be expressed in terms of mass fluxes across cell interfaces. Therefore, velocity-pressure decoupling cannot occur.

Table IV. Comparison of Three CZ Treatments

\begin{tabular}{|c|c|c|c|}
\hline \multirow[b]{2}{*}{ Treatments } & \multicolumn{2}{|c|}{ Nonlayered treatments } & \multirow[b]{2}{*}{ Layered Treatment } \\
\hline & Isotropic & Anisotropic & \\
\hline \multicolumn{4}{|l|}{ Variables } \\
\hline Solid volume fraction & \multirow{2}{*}{\multicolumn{2}{|c|}{$\begin{array}{c}\varepsilon_{\mathrm{s}}=\xi_{\text {ore }} \varepsilon_{\text {ore }}+\xi_{\text {coke }} \varepsilon_{\text {coke }} \\
d_{\mathrm{s}}=\left(\frac{\xi_{\text {ore }}}{d_{\text {ore }}}+\frac{\xi_{\text {coke }}}{d_{\text {coke }}}\right)^{-1}\end{array}$}} & $\int \phi_{\text {ore }}$ for ore layer \\
\hline Solid particle size & & & $\phi_{\mathrm{s}}= \begin{cases}\phi_{\mathrm{coke}} & \text { for coke layer }\end{cases}$ \\
\hline Solid heat conductivity & \multicolumn{2}{|c|}{$k_{\mathrm{s}}=\left(\frac{\xi_{\text {ore }}}{k_{\text {ore }}}+\frac{\xi_{\text {coke }}}{k_{\text {coke }}}\right)$} & where $\phi=\varepsilon, d, k$ \\
\hline \multirow[t]{2}{*}{ Gas flow resistance in $\mathrm{CZ}$} & $\alpha_{\mathrm{f}}=a \frac{1-\varepsilon_{\mathrm{s}}}{d_{\mathrm{s}}}$ & $\begin{array}{l}\text { Vertical to the layer } \\
\alpha_{\mathrm{f}}=\xi_{\text {ore }} \alpha_{\text {ore }}+\xi_{\text {coke }} \alpha_{\text {coke }} \\
\beta_{\mathrm{f}}=\xi_{\text {ore }} \beta_{\text {ore }}+\xi_{\text {coke }} \beta_{\text {coke }}\end{array}$ & For ore layer $\alpha_{\mathrm{f}}=\alpha_{\mathrm{ore}}, \beta_{\mathrm{f}}=\beta_{\text {ore }}$ \\
\hline & $\beta_{\mathrm{f}}=b \frac{\mu_{g}\left(1-\varepsilon_{\mathrm{s}}\right)^{2}}{d_{\mathrm{s}}^{2} \varepsilon_{\mathrm{s}}}$ & $\begin{array}{l}\text { Parallel to the layer } \\
\alpha_{\mathrm{f}}=\left(\frac{\xi_{\text {ore }}}{\sqrt{\alpha_{\text {ore }}}}+\frac{\xi_{\text {coke }}}{\sqrt{\alpha_{\text {coke }}}}\right)^{-2} \\
\beta_{\mathrm{f}}=\left(\frac{\xi_{\text {ore }}}{\beta_{\text {ore }}}+\frac{\xi_{\text {coke }}}{\beta_{\text {coke }}}\right)^{-1}\end{array}$ & For coke layer $\alpha_{\mathrm{f}}=\alpha_{\text {coke }}, \beta_{\mathrm{f}}=\beta_{\text {coke }}$ \\
\hline
\end{tabular}


Convective terms were discretized by the upwind scheme in which quantities at cell faces were determined by assuming that the cell-center value of any field variable represented a cell-average value and held throughout the entire cell. For the discretization of viscous transport terms in the momentum equations, the central finite difference approximation with secondorder spatial truncation errors was used. The GreenGauss theorem was used to compute the gradient of the scalar at the cell center. Strong under-relaxation was applied in the temperature and concentration field calculations. A linearization of source terms related to the generation of phase species and reaction heat had to be introduced for physical boundness, i.e., maxima or minima of process variables was within a reasonable range. ${ }^{[50]}$ The strongly implicit procedure ${ }^{[51]}$ was used to solve the discretized equations with the large sparse linear matrix. The deadman boundary for the solid flow field was determined with a solid isovelocity curve. ${ }^{[52]}$ The SIMPLE algorithm ${ }^{[50]}$ was used to couple velocity and pressure drop of continuous phases. The main procedure used to calculate liquid flow is detailed elsewhere. ${ }^{[53]}$

As shown in Figure 2, the well-established sequential solution procedure was employed in the current study to calculate the coupled fluid flow, heat transfer, and chemical reactions. First, the (initial) gas, solid, and liquid flow, temperature, as well as concentration fields were determined under the boundary conditions at the inlets, outlets, and walls. The layered structure was determined based on the burden distribution at the BF top (e.g., the ore and coke batch weights as well as the ore-coke ratio) and the timelines of solid flow-a technique used in the previous studies of gas-solid flow in a BF. ${ }^{[30,52]}$ Then, the flow, temperature, and concentration fields were calculated without considering the chemical reactions until an approximate convergence (i.e., high tolerance) in terms of mass and energy residuals was obtained. Finally, thermalchemical behavior was taken into account, which lead to the $\mathrm{CZ}$ determination, and with this information, fluid flow, heat and mass transfer, as well as chemical reactions were recalculated. This procedure was repeated until the $\mathrm{CZ}$ position converged. In this study, the criterion for convergence was set to $10 \mathrm{pct}$ of the relative $\mathrm{CZ}$ positions in two consecutive iterations. The error was somehow large compared with those for the convergence of gas, liquid, and solid flows in the computation. This was because the estimated $\mathrm{CZ}$ tended to oscillate under some conditions. But considering the complexity of the problem, the resulting error in $\mathrm{BF}$ performance prediction was small.

\section{SIMULATION CONDITIONS}

Numerical simulations were performed under conditions similar to a BF of $\sim 1000 \mathrm{~m}^{3}$ inner volume (hearth diameter of $7.2 \mathrm{~m}$, height of $25 \mathrm{~m}$ ). Assuming the symmetrical distribution of process variables, only half the BF geometry was considered in the simulation and was treated as a two-dimensional slot model for

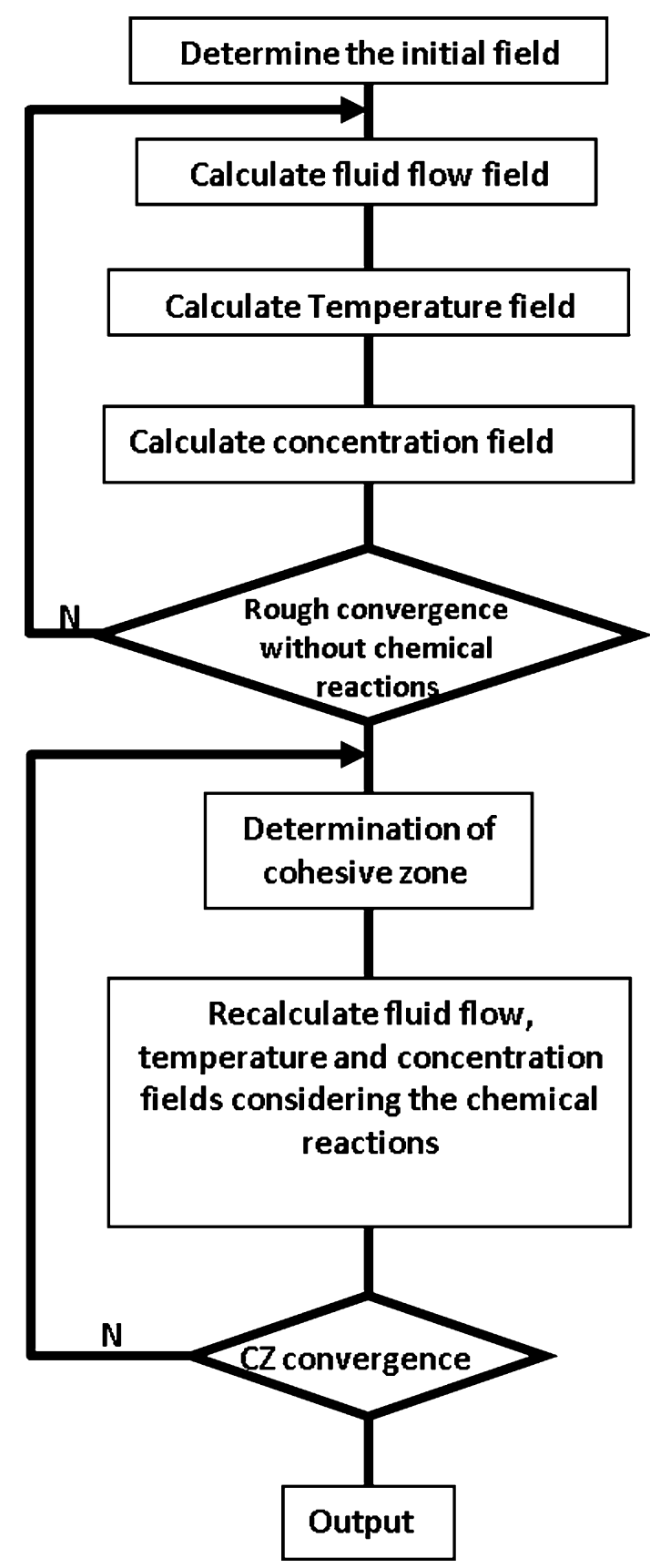

Fig. 2-Solution procedure in which a rectangular-shaped box represents a calculation step and a diamond-shaped box represents a decision step.

simplicity. Generally, the starting thickness of a $\mathrm{CZ}$ ore layer was around $30 \mathrm{~cm}$. To model the $\mathrm{CZ}$ at a sufficient level of detail, the whole computational domain was divided into $298 \times 38$ nonuniform control volumes in the Cartesian coordinates. Each computational cell was then around $8 \mathrm{~cm} \times 9 \mathrm{~cm}$. The corresponding computational domain and an enlargement of the cells in lower region are shown in Figure 3. Gas was injected to the $\mathrm{BF}$ through a lateral inlet (tuyere) occupying four consecutive cells at the wall in the furnace lower zone. Solids (ore, coke, and flux) were charged from the top of the furnace with a uniform 
downward velocity along the horizontal direction. The basic operating data of the modeled $\mathrm{BF}$-calculated using a heat and mass balance - are summarized in Table V. During the simulation, the productivity in a unit volume was first calculated based on the data provided in Table $\mathrm{V}$, then consistent gas, ore, coke, and flux rates were determined that assumed a twodimensional profile with unit thickness. The liquids, hot metal, and slag were assumed to be generated at the lower side of the melting subregion within the $\mathrm{CZ}$, with flow rates determined from the total amount of liquid, inlet area, and ore-coke ratio. For typical conditions, the gas mass flow rate was $11.7 \mathrm{~kg} \times \mathrm{m}^{-2} \times \mathrm{s}^{-1}$ at the tuyere; solid flow rate was $1.22 \mathrm{~kg} \times \mathrm{m}^{-2} \times \mathrm{s}^{-1}$; and liquid slag and hot metal flow rates were dependent on the liquid inlet area calculated during the simulation. Contemporary intensive BF operation required a high top pressure, with a constant $2 \mathrm{~atm}$ assumed for all simulations. Average solid particle sizes and ore-coke ratio were as shown in Table $\mathrm{V}$, with a nonuniform distribution of these variables imposed along the horizontal direction, as discussed later.

In practice, with the demands of smooth operation and high productivity, burden distribution often was adjusted to improve the gas flow in the furnace, which is key to BF operations. Good hot-metal quality also largely was achieved through appropriate control of burden distribution. In the current simulations, the burden distribution and particle sizes, as the input information, were assumed, as shown in Figure 4. Note that ore particle size was assumed to be constant, but coke particle size was assumed to change with the orecoke volume ratio. With this information, physical properties of the mixture of ore and coke, such as particle diameter and porosity, could be calculated. In this case, the ore-coke ratio was low at the center, and the coke particle size was small near the furnace wall. This burden distribution provided a high permeability at the furnace center because large particles induced large voids and presented a low surface area-volume ratio to passing fluids. Initially, the particle properties imposed at the top of the furnace were extended to the lower part so that particle size and porosity distributions in the entire furnace could be obtained. During the calculation, with the identification of the $\mathrm{CZ}$, coke zone, and deadman, the properties in these regions were reestimated to replace the initial values based on the following rules: (1) in the CZ, porosity and particle size of iron-bearing materials were a function of normalized shrinkage ratio, $S h_{r}^{*}$; (2) in the coke zone, bed permeability was calculated based on coke size only; and (3) in the deadman, coke size and porosity were assumed as $\mathrm{d}_{\mathrm{s}}=0.02 \mathrm{~m}$ and $\varepsilon_{\mathrm{s}}=0.65$. In practice, because of the importance of burden distribution to furnace operations, these conditions should be reset with reference to equipment setpoints and measured data from actual $\mathrm{BF}$ operations or laboratory scale tests.

\section{RESULTS AND DISCUSSION}

\section{A. Effect of CZ Treatment on Gas Flow}

The CZ has a significant effect on the fluid flow, as demonstrated by previous studies. ${ }^{[2-5]}$ In particular, the layered $\mathrm{CZ}$ can make the gas flow significantly change

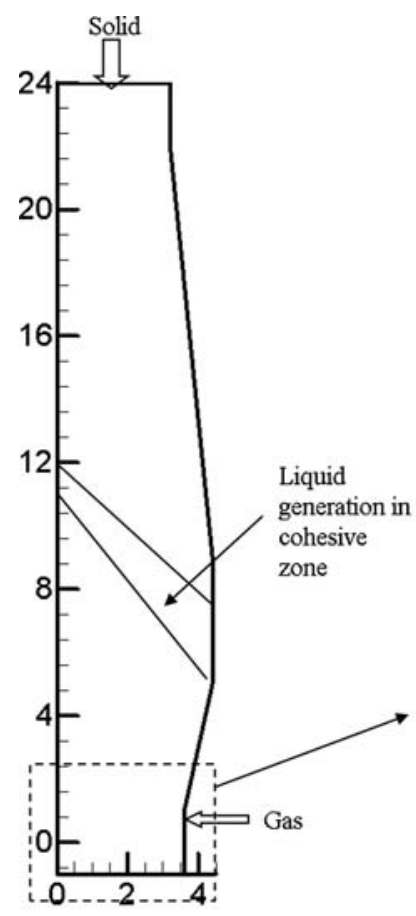

(a)

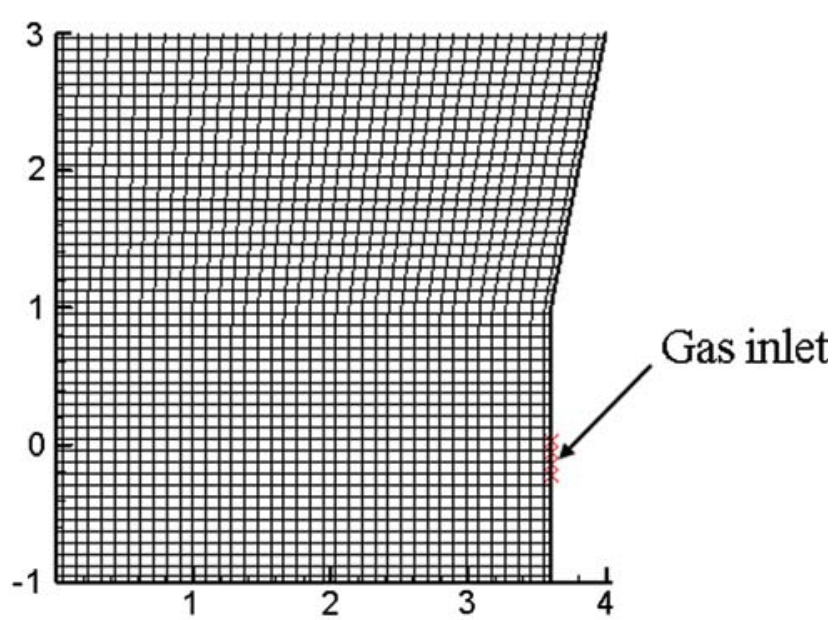

(b)

Fig. 3-(a) Compuational domain and $(b)$ the grid arrangement in an enlarged local region. 
Table V. Operational Conditions Considered in this Work

\begin{tabular}{|c|c|}
\hline Variables & $\mathrm{BF}$ \\
\hline \multicolumn{2}{|l|}{ Gas: } \\
\hline Volume flux, $\mathrm{Nm}^{3} \times \mathrm{tHM}^{-1}$ & 1511 \\
\hline \multirow{5}{*}{$\begin{array}{l}\text { Inlet gas components, mole } \\
\text { percentage }\end{array}$} & 34.95 pet $\mathrm{CO}$ \\
\hline & 0.0 pct $\mathrm{CO}_{2}$ \\
\hline & 0.81 pct $\mathrm{H}_{2}$ \\
\hline & 0.0 pct $\mathrm{H}_{2} \mathrm{O}$ \\
\hline & 64.23 pct $\mathrm{N}_{2}$ \\
\hline Inlet gas temperature, $\mathrm{K}$ & 2313.6 \\
\hline Top pressure, atm & 2.0 \\
\hline \multicolumn{2}{|l|}{ Solid: } \\
\hline Ore, $\mathrm{t} \times \mathrm{tHM}^{-1}$ & 1.64 \\
\hline \multirow[t]{8}{*}{ Ore components, mass fraction } & $\mathrm{Fe}_{2} \mathrm{O}_{3} 0.656$ \\
\hline & $\mathrm{FeO} 0.157$ \\
\hline & $\mathrm{CaO} 0.065$ \\
\hline & $\mathrm{MgO} 0.024$ \\
\hline & $\mathrm{SiO}_{2} 0.059$ \\
\hline & $\mathrm{Al}_{2} \mathrm{O}_{3} 0.029$ \\
\hline & $\mathrm{MnO} 0.006$ \\
\hline & $\mathrm{P}_{2} \mathrm{O}_{5} 0.008$ \\
\hline Average ore particle size, $\mathrm{m}$ & 0.03 \\
\hline Coke, $\mathrm{t} \times \mathrm{tHM}^{-1}$ & 0.5023 \\
\hline \multirow[t]{5}{*}{ Coke components, mass fraction } & C 0.857 \\
\hline & Ash 0.128 \\
\hline & S 0.005 \\
\hline & H 0.005 \\
\hline & $\mathrm{N} 0.005$ \\
\hline Average coke particle size, $\mathrm{m}$ & 0.045 \\
\hline Flux, $\mathrm{t} \times \mathrm{tHM}^{-1}$ & 0.0264 \\
\hline \multirow[t]{6}{*}{ Flux components, mass fraction } & $\mathrm{CaO} 0.438$ \\
\hline & $\mathrm{MgO} 0.079$ \\
\hline & $\mathrm{SiO}_{2} 0.024$ \\
\hline & $\mathrm{Al}_{2} \mathrm{O}_{3} 0.033$ \\
\hline & $\mathrm{CO}_{2}$ in $\mathrm{CaO} 0.344$ \\
\hline & $\mathrm{CO}_{2}$ in $\mathrm{MgO} 0.082$ \\
\hline Ore voidage & $0.403\left(100 \mathrm{~d}_{\text {ore }}\right)^{0.14}$ \\
\hline Coke voidage & $0.153 \log \mathrm{d}_{\text {coke }}+0.72$ \\
\hline Average ore/(ore + coke $)$ & 0.5923 \\
\hline volume ratio & \\
\hline \multicolumn{2}{|l|}{ Liquid: } \\
\hline \multirow{7}{*}{$\begin{array}{l}\text { Hot metal rate, } \mathrm{t} \times \mathrm{day}^{-1} \\
\quad \text { components, mass fraction }\end{array}$} & 2034 \\
\hline & C 0.04 \\
\hline & Si 0.004 \\
\hline & Mn 0.0045 \\
\hline & P 0.0003 \\
\hline & S 0.0003 \\
\hline & $\mathrm{Fe} 0.9509$ \\
\hline density, $\mathrm{kg} \times \mathrm{m}^{-3}$ & 6600 \\
\hline viscosity, $\mathrm{kg} \times \mathrm{m}^{-1} \times \mathrm{s}^{-1}$ & 0.005 \\
\hline conductivity, $\mathrm{w} \times \mathrm{m}^{-1} \times \mathrm{K}^{-1}$ & 28.44 \\
\hline surface tension, $\mathrm{N} \times \mathrm{m}^{-1}$ & 1.1 \\
\hline \multirow{8}{*}{$\begin{array}{l}\text { Slag rate, } \mathrm{t} \times \mathrm{tHM}^{-1} \\
\text { components, mass fraction }\end{array}$} & 0.377 \\
\hline & $\mathrm{CaO} 0.324$ \\
\hline & $\mathrm{MgO} 0.120$ \\
\hline & $\mathrm{SiO}_{2} 0.324$ \\
\hline & $\mathrm{Al}_{2} \mathrm{O}_{3} 0.200$ \\
\hline & $\mathrm{FeO} 0.016$ \\
\hline & $\mathrm{MnO} 0.009$ \\
\hline & S 0.007 \\
\hline density, $\mathrm{kg} \times \mathrm{m}^{-3}$ & 2600 \\
\hline viscosity, $\mathrm{kg} \times \mathrm{m}^{-1} \times \mathrm{s}^{-1}$ & 1.0 \\
\hline conductivity, $\mathrm{w} \times \mathrm{m}^{-1} \times \mathrm{K}^{-1}$ & 0.57 \\
\hline surface tension, $\mathrm{N} \times \mathrm{m}^{-1}$ & 0.47 \\
\hline
\end{tabular}

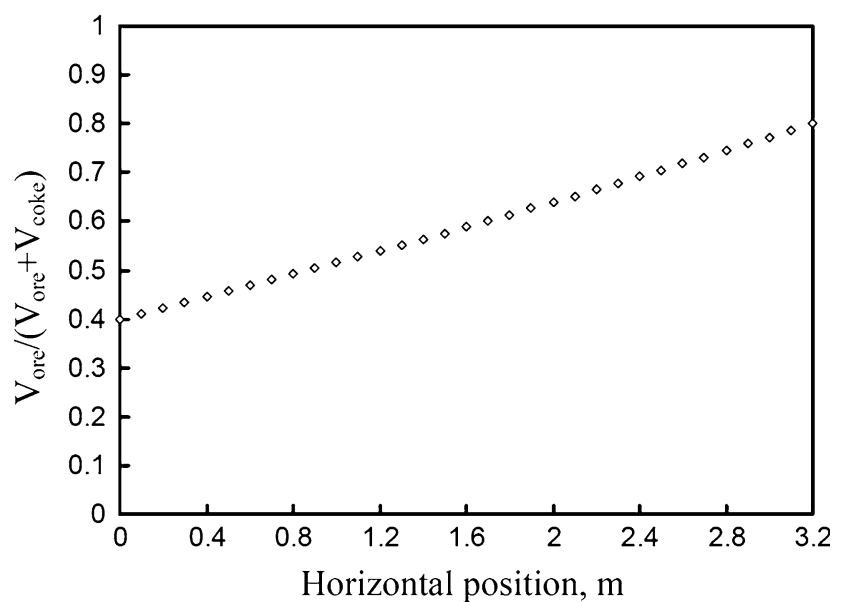

(a)

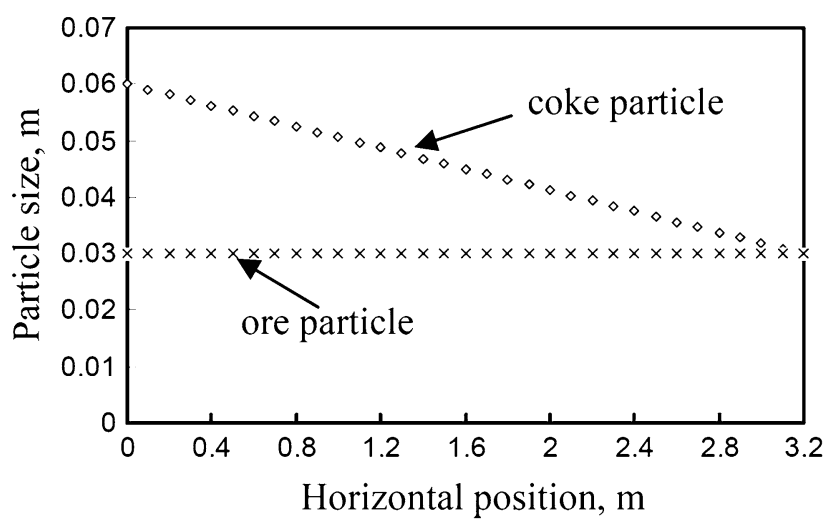

(b)

Fig. 4-Top-burden distribution: $(a)$ volume ratio of iron ore and (b) particle size.

direction and force liquid to flow horizontally between the fused layers. However, the effect of different CZ treatments on the modeling of fluid flow has not been compared critically. To exclude the influence of other factors, the comparison was first carried out under a simplified condition, i.e., without considering solid and liquid flow, heat and mass transfer, as well as chemical reactions. In this case, the position and structure of layered and nonlayered cohesive zones were assumed. Figure 5 shows the fixed $\mathrm{CZ}$ structure and porosity distribution for layered and nonlayered $\mathrm{CZ}$ treatments. Here porosity referred to the interconnected pore space between particles or through a partially fused layer in the $\mathrm{CZ}$ that was accessible to gases and liquids. Note that for anisotropic and isotropic nonlayered treatments, the $\mathrm{CZ}$ structure and porosity distribution were the same. Boundary conditions are given in Table V. The computational domain encompassed the lumpy zone $\mathrm{CZ}$, dripping zone, and solid stagnant region (deadman). Except for the $\mathrm{CZ}$ region, computational conditions were the same for the three $\mathrm{CZ}$ treatments considered. Within the $\mathrm{CZ}$, the layered structure comprised low-permeability softening and melting layers as 


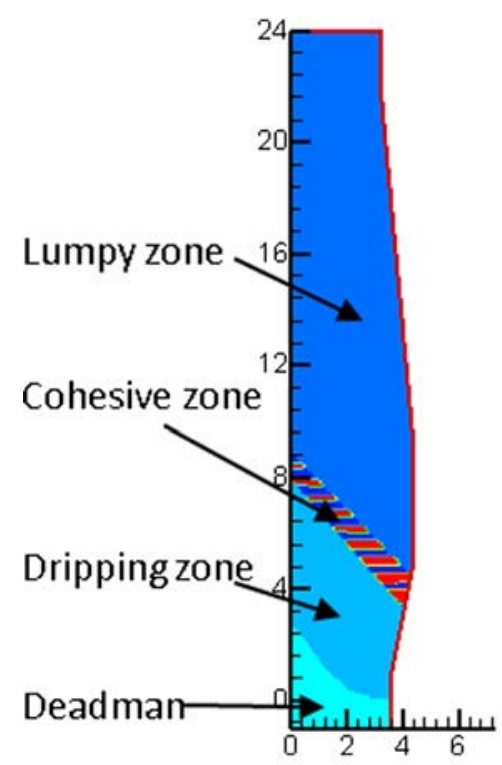

(a)

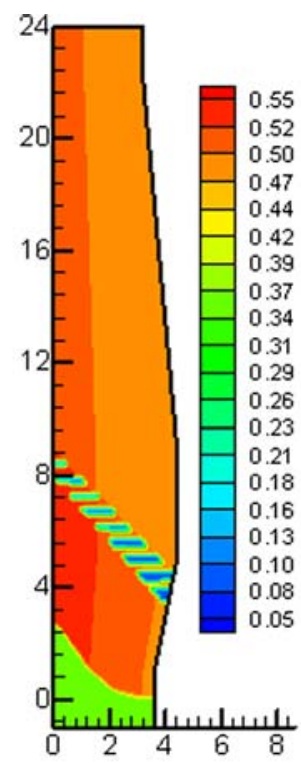

(b)

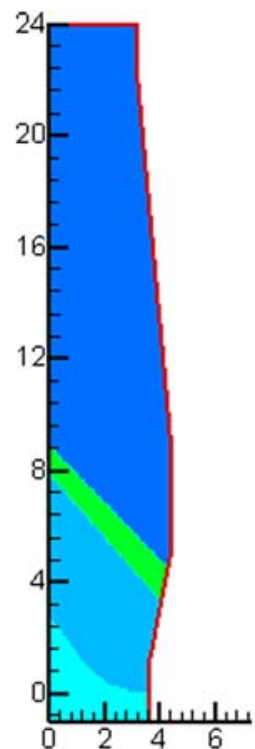

(c)

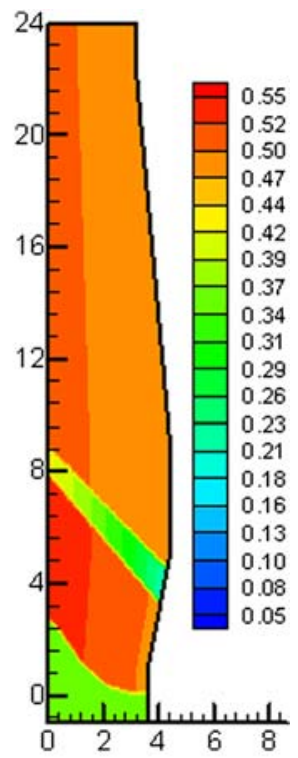

(d)

Fig. 5-Computational domains and porosity distributions for different CZ treatments; CZ position for (a) layered and (c) nonlayered; porosity distribution for $(b)$ layered and $(d)$ nonlayered.

well as highly permeable coke layers as shown in Figures 5(a) and (b). Porosity in the softening and melting layers was assumed to reach a minimum of 20 pct of the initial ore voidage - calculated according to the correlation given in Table V. Correspondingly, particle size in the softening and melting layers was assumed to reach a minimum of 40 pct of average oreparticle size. With the same ore-coke volume ratio in the $\mathrm{CZ}$ and the same particle size and porosity assumptions for iron-bearing materials and coke as those used for the earlier layered treatment, porosity in the nonlayered CZ was determined for the mixture of iron-bearing materials and coke as shown in Figure 5(d).

Figure 6 shows the calculated gas flow field for different $\mathrm{CZ}$ treatments. All cases demonstrated that the $\mathrm{CZ}$ acts as a gas distributor so that the flows deviate through the CZ. However, these deviations were different for the three treatments. Gas flowed more horizontally through the $\mathrm{CZ}$ for layered and anisotropic nonlayered treatments than for the isotropic nonlayered treatment, which is consistent with other studies. ${ }^{[26,34]}$ However, in essence, the reason why gas flowed horizontally is different. As shown in Figure 6(d), for the layered $\mathrm{CZ}$ treatment, the lower permeability of the ore layer made the gas preferentially flow through the high permeability coke layer. In contrast, for the anisotropic CZ treatment, gas flowed horizontally through the entire $\mathrm{CZ}$ because of the large axial resistance in this region.

Pressure drop is a primary indicator that represented the permeability and gas resistance in the furnace. Figure 7 shows the corresponding pressure distributions for the three $\mathrm{CZ}$ treatments (NB. Pressure drop shown in the figure was relative to the top pressure). Large pressure gradients existed in the $\mathrm{CZ}$ region, which indicate the sudden change of bed permeability for all the treatments. Among the three treatments, the pressure drop for the anisotropic CZ was the highest, although little difference was observed in pressure drop between the layered and isotropic nonlayered treatments, as demonstrated by the pressure distributions at different heights in Figure 8.

Although, in this section, heat transfer and chemical reactions have not been considered, the comparisons discussed show that an anisotropic CZ treatment is inclined to predict high gas flow resistance because the low permeability of iron-bearing materials dominated the calculation of resistance throughout the $\mathrm{CZ}$ in the axial direction and strongly influenced resistance in the radial direction. In contrast, the pressure drop calculated for the isotropic CZ treatment was less because the averaged properties of the layers were less strongly influenced by the low permeability ore. Although the anisotropic treatment seemed conceptually more realistic than the isotropic treatment, the significant increase in pressure drop through the $\mathrm{CZ}$ in the former case relative to the layered treatment suggested that the formulation of gas flow resistance in the radial direction may need to be reconsidered in the future.

Nonetheless, it is clear that different CZ treatments will result in different flow behavior and pressure distribution, which in turn, will result in a different influence on the thermal and chemical behavior including the $\mathrm{CZ}$ position and the other process performance as discussed in the following.

\section{B. Effect of CZ Treatment on Process Performance}

In this section, the three $\mathrm{CZ}$ treatments were applied to $\mathrm{BF}$ modeling with heat transfer and chemical 


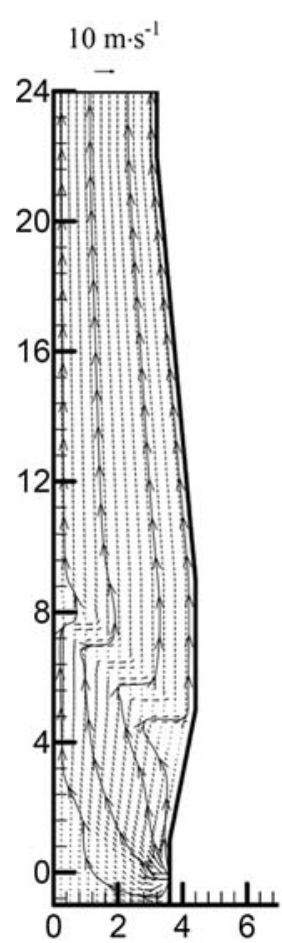

(a)

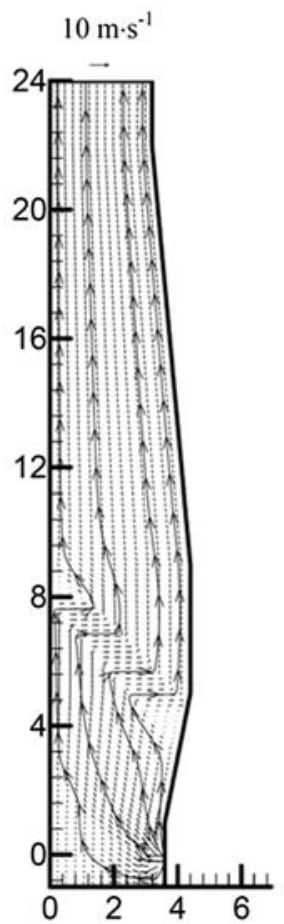

(b)

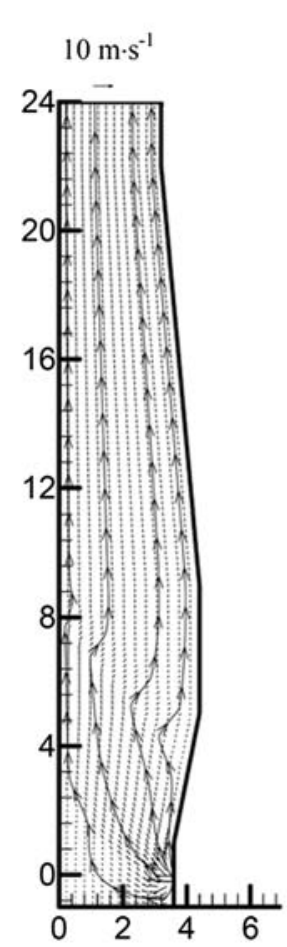

(c)

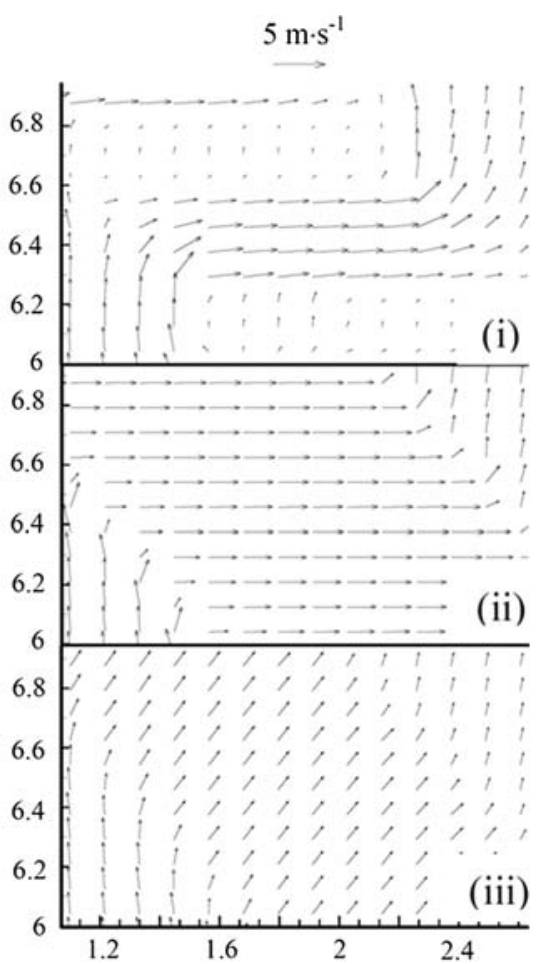

(d)

Fig. 6- Gas flow fields for $(a)$ layered, $(b)$ anisotropic nonlayered, $(c)$ isotropic nonlayered treatments, and $(d)$ enlarged CZ, which are listed in parts ( $i$ ) layered, (ii) anisotropic nonlayered, and (iii) isotropic nonlayered. Note that the reference vectors are given on the top of each subfigure.

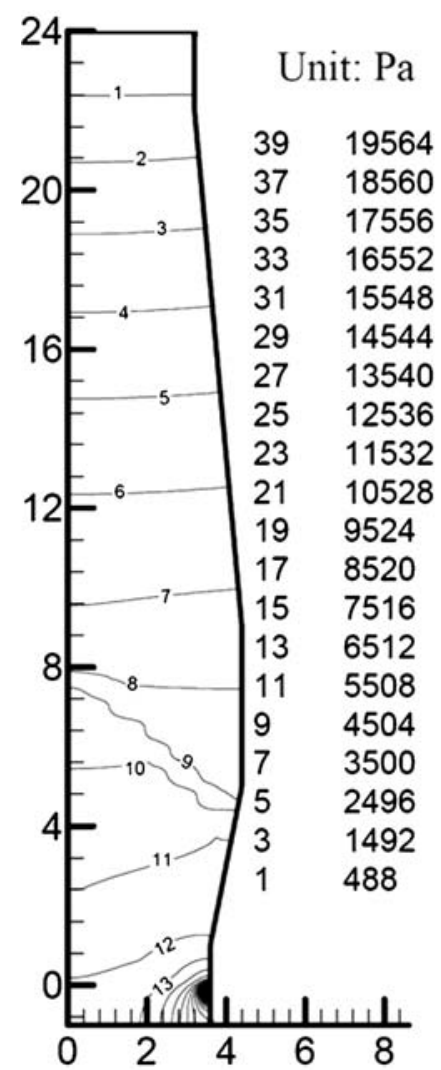

(a)

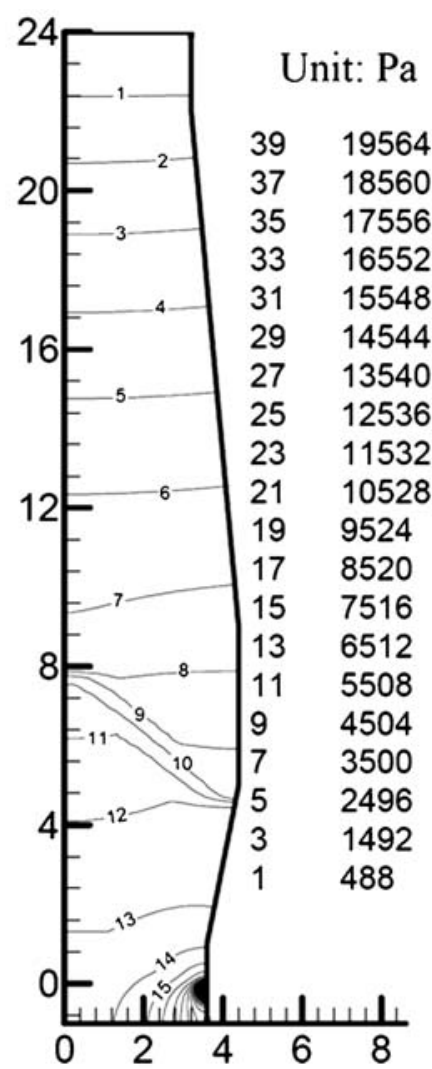

(b)

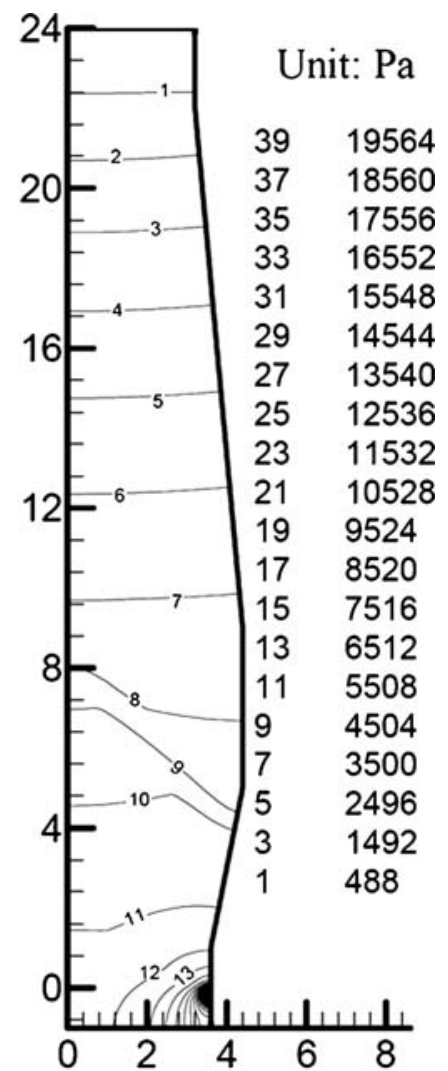

(c)

Fig. 7-Pressure distributions for $(a)$ layered, $(b)$ anisotropic nonlayered, and $(c)$ isotropic nonlayered treatments. 


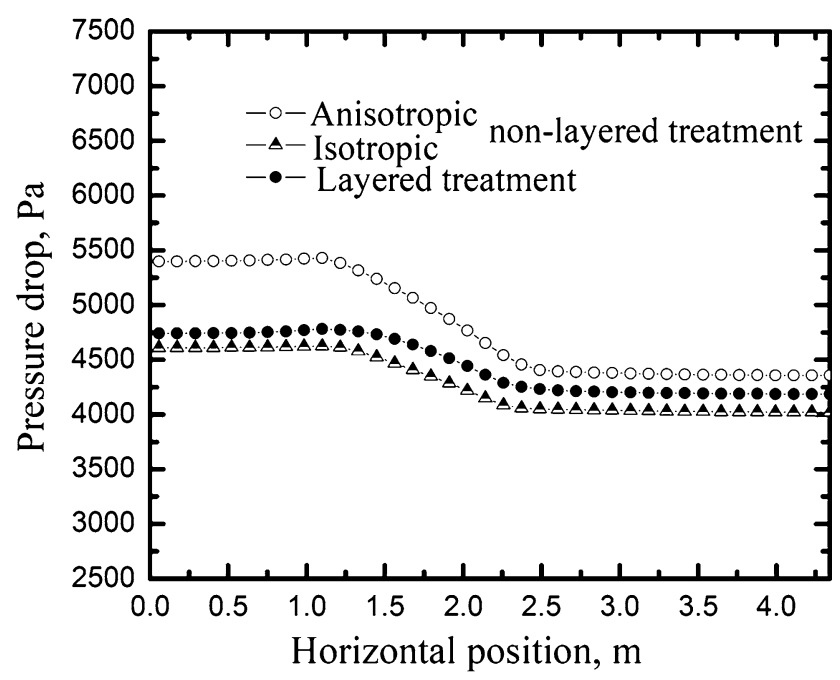

(a)

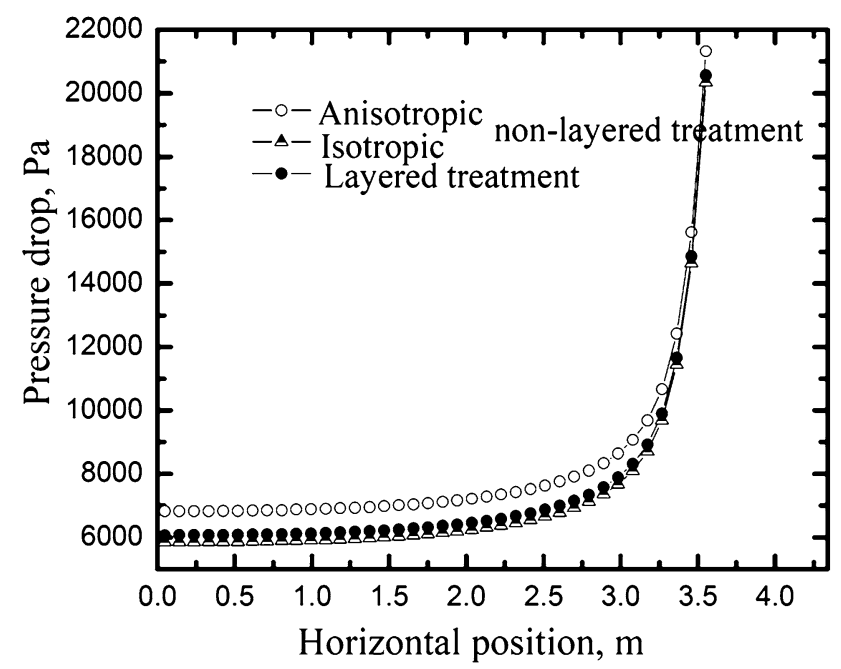

(b)

Fig. 8-Pressure distribution for different CZ treatments (a) at a height of $6.5 \mathrm{~m}$ and $(b)$ at tuyere level.

reactions. Instead of a fixed position, the $\mathrm{CZ}$ was predicted for the three different treatments based on the same boundary and operational conditions. In the simulations, the $\mathrm{CZ}$ region was defined to be within the temperature range of $1473-1673 \mathrm{~K}$, as described in the numerical modeling section. The shrinkage ratio $S h_{\mathrm{r}}$, which is the most commonly used parameter to represent the softening and melting status of iron-bearing materials, was applied to determine the particle size and porosity of iron-bearing materials in the CZ. A linear relationship between the shrinkage ratio and the temperature was used, as shown in Figure 9(a). Corresponding relationships between normalized porosityparticle size and shrinkage ratio were assumed, as shown in Figures 9(b) and (c). The relationships encompassed the three states of iron-bearing materials discussed.

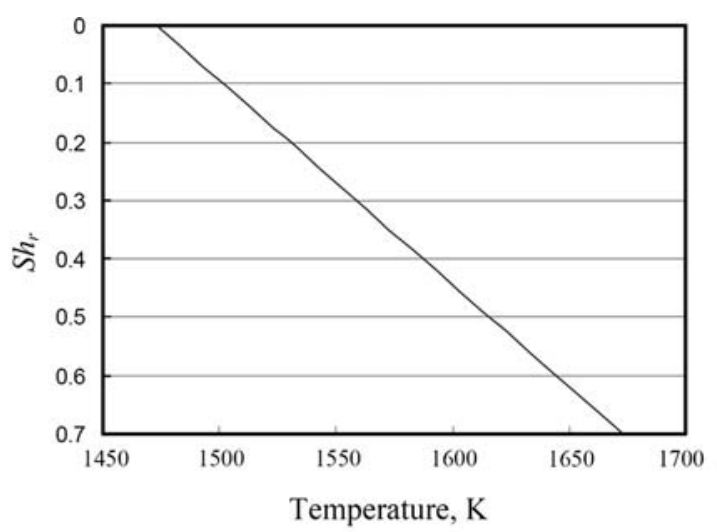

(a)

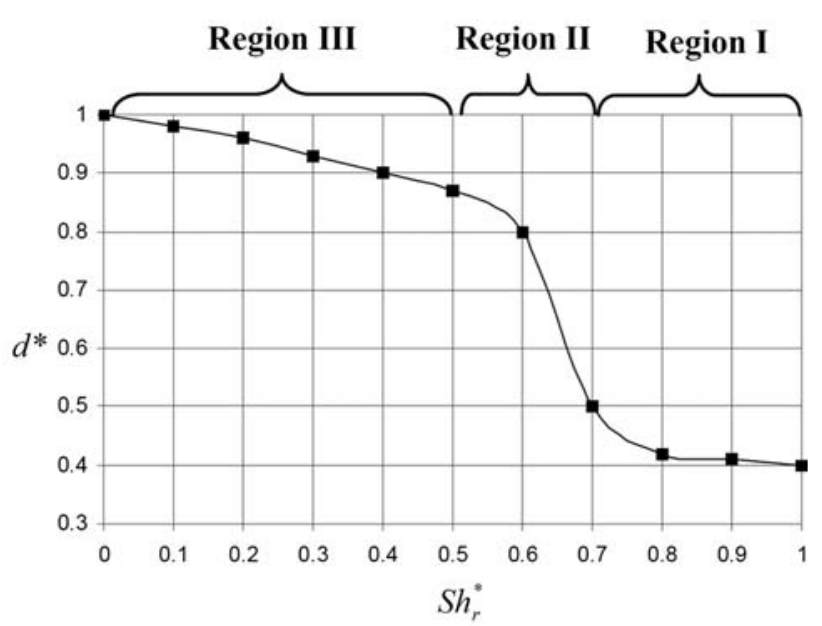

(b)

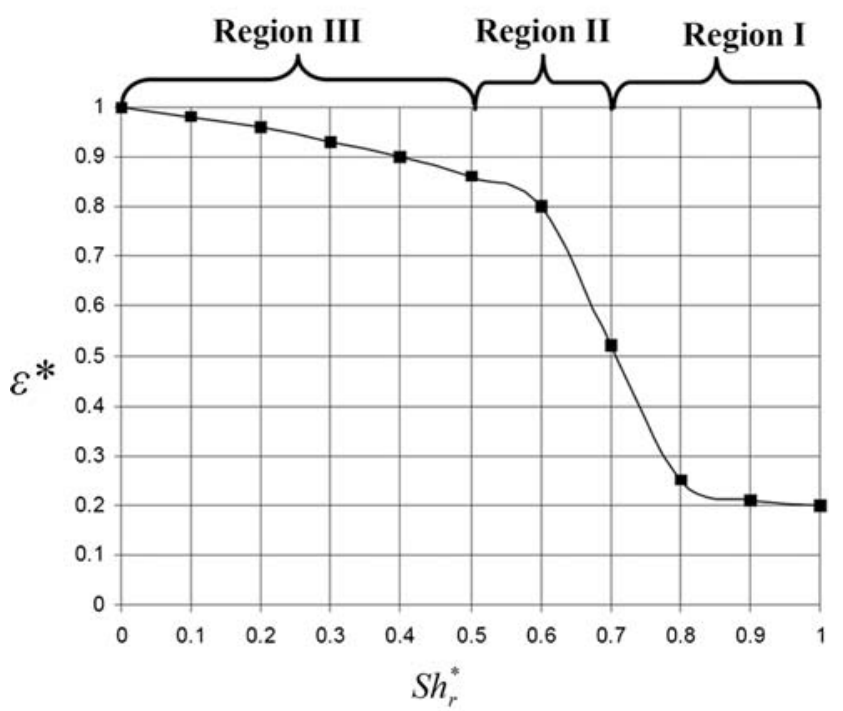

(c)

Fig. 9-Relationship between (a) shrinkage ratio and temperature, between $(b)$ normalized shrinkage ratio and particle size for ironbearing materials in the $\mathrm{CZ}$, and between $(c)$ normalized shrinkage ratio and porosity for iron-bearing materials in the $\mathrm{CZ}$. 


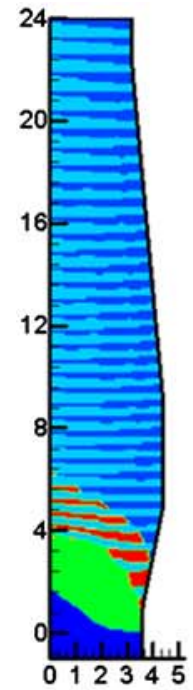

(a)

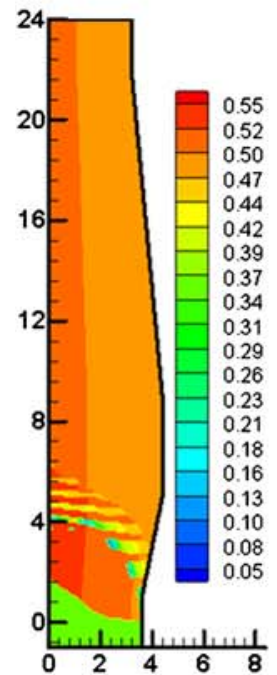

(d)

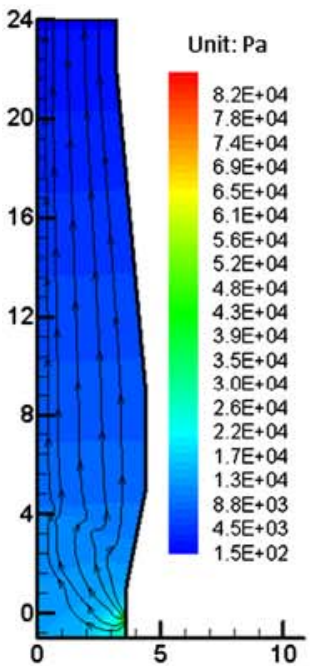

(g)

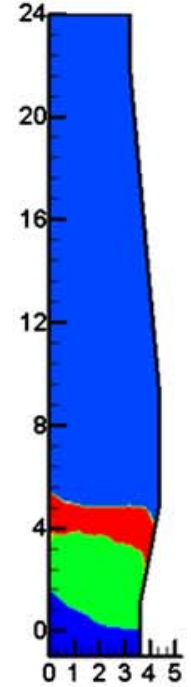

(b)

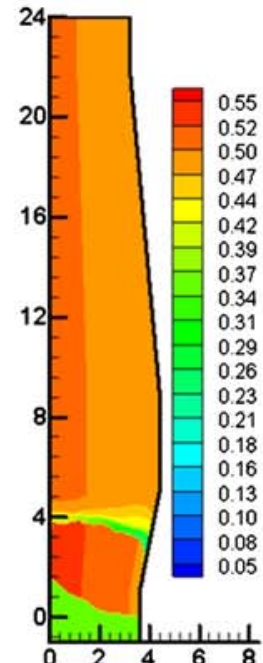

(e)

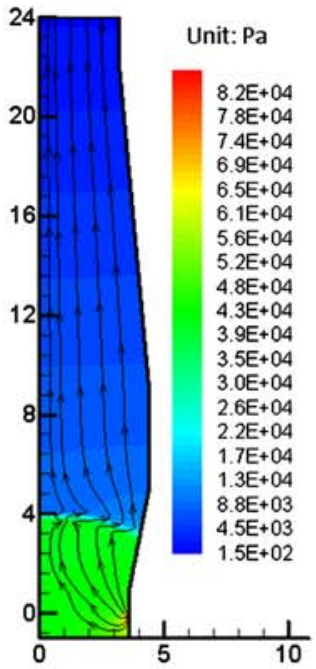

(h)

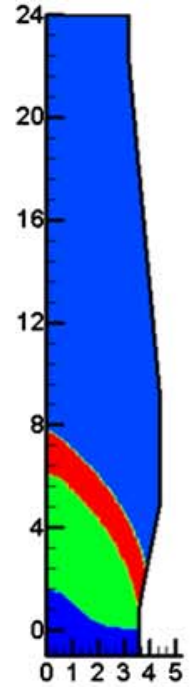

(c)

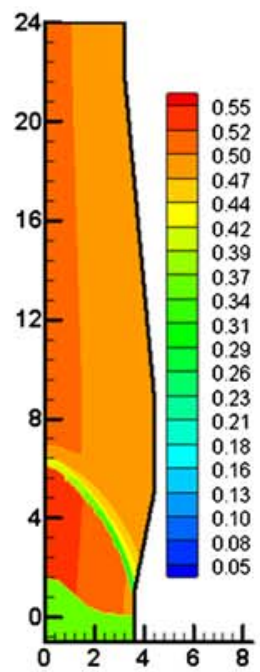

(f)

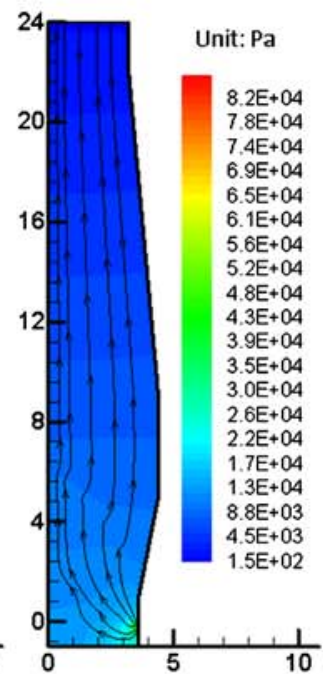

(i)

Fig. 10- CZ shapes $(a)-(c)$, porosity distributions $(d)-(f)$, as well as pressure drop distribution and gas flow stream line $(g)-(i)$ for the following CZ treatments: left column, layered; middle column, anisotropic nonlayered; and right column, isotropic nonlayered. Note that the minimum porosity can reach 0.094 in the layered cohesive zone. 
$20 \mathrm{~m} \cdot \mathrm{s}^{-1}$

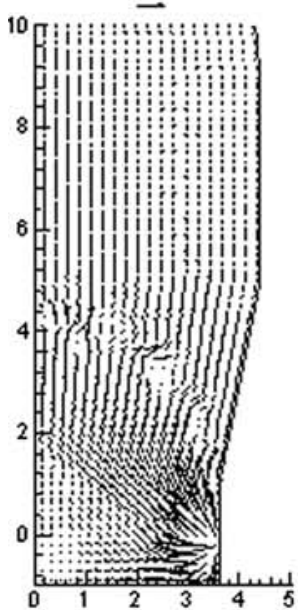

(a)

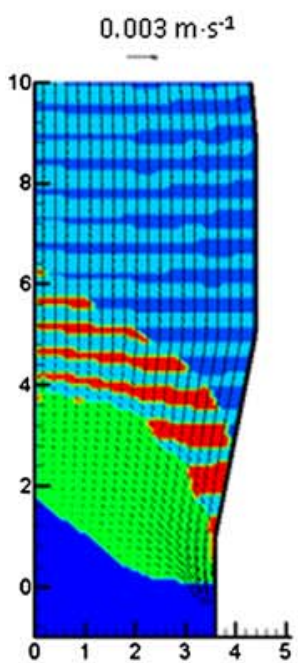

(d)

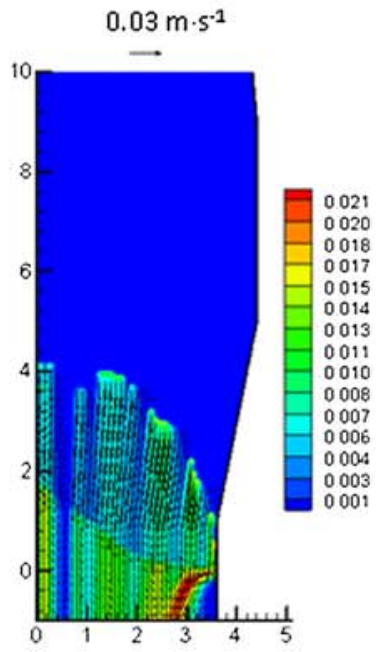

(g)
$20 \mathrm{~m} \cdot \mathrm{s}^{-1}$

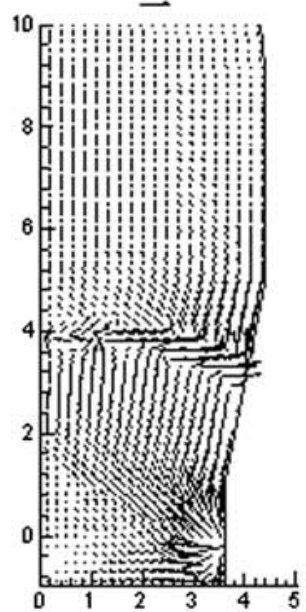

(b)

$0.003 \mathrm{~m} \cdot \mathrm{s}^{-1}$

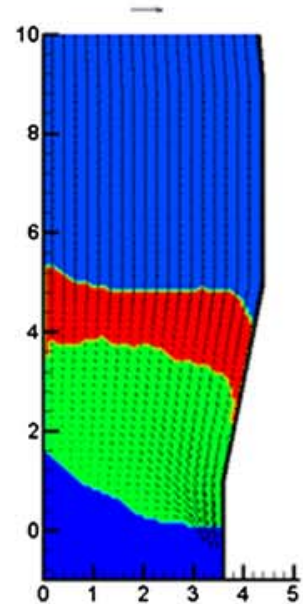

(e)

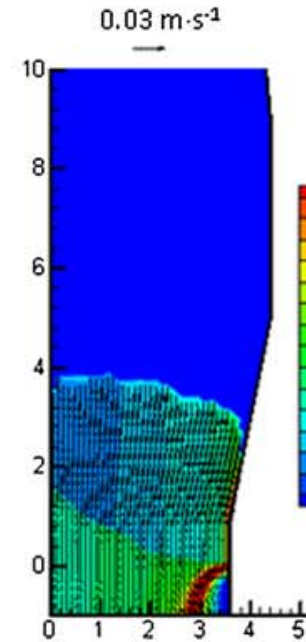

(h)
$20 \mathrm{~m} \cdot \mathrm{s}^{-1}$

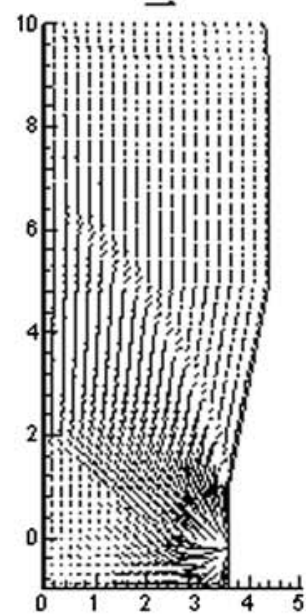

(c)

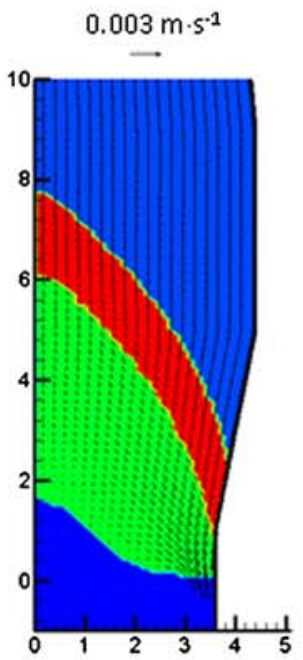

(f)

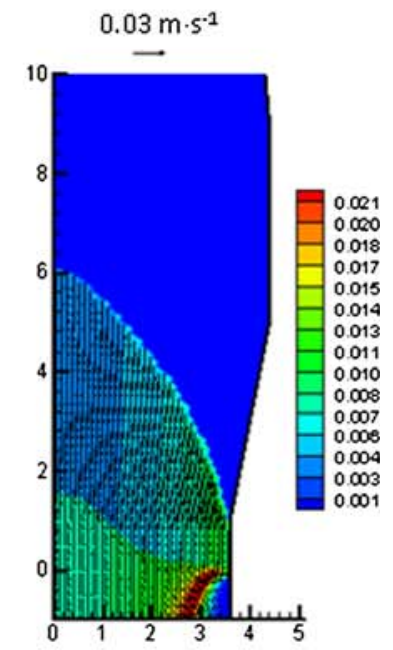

(i)

Fig. 11-Gas $(a)-(c)$, solid $(d)-(f)$, and liquid slag $(g)-(i)$ flow field for the following three CZ treatments: left column, layered; middle column, anisotropic nonlayered; and right column, isotropic nonlayered. 
Figure 10(a) shows that an inverse- $V$ shaped $C Z$ structure was obtained using the layered $\mathrm{CZ}$ treatment. In the layered CZ, iron-bearing materials and coke were distributed alternately so that permeable coke windows could form. Softening- and melting-ore layers comprised the following three regions corresponding to the defined states: (1) Region I where blockage of the bed porosity was nearly complete by the melting of solids; (2) Region II where a combination of softening and melting of iron-bearing materials were present; and (3) Region III where iron-bearing materials only underwent softening, which occupied the greatest portion of the $\mathrm{CZ}$. Although the $\mathrm{CZ}$ was modeled as a mixed region of iron-bearing materials and coke for both cases, for the nonlayered $\mathrm{CZ}$ treatments, the different resistances along the vertical direction led to different $\mathrm{CZ}$ shapes, i.e., a horizontal $\mathrm{CZ}$ for the anisotropic nonlayered treatment and an inverse- $\mathrm{V} \mathrm{CZ}$ for the isotropic nonlayered treatment, as shown in Figures 10(b) and (c).

Corresponding to these modeled CZs, porosity distributions were as shown in Figures 10(d)-(f). In the lumpy and dripping zones, a high permeability was observed at the furnace center and a low permeability region was observed near the wall. Within the $\mathrm{CZ}$, high and low permeability regions were stratified for the layered treatment, whereas the permeability gradually increased from the lower to upper part of the CZ for the other two treatments. It must be noted that a complex interaction occurred between the gas flow and the porosity variation caused by the softening and melting of the burden because it is the gas flowing through the burden that eventually causes iron-bearing materials to soften and become impermeable to gas flow. To demonstrate this relationship, the corresponding gas flow and pressure drop distributions are illustrated in Figures $10(\mathrm{~g})-(\mathrm{i})$, where the variation of gas flow direction corresponded to the porosity variation. Among these treatments, the variation of gas flow direction in the $\mathrm{CZ}$ for the anisotropic treatment was the most intensive and a marked increase in pressure drop occurred in the $\mathrm{CZ}$, which reflected the highest predicted resistance. However, the results show that different $\mathrm{CZ}$ treatments only affect the pressure drop distribution in the lower part of the BF, and their influence becomes insignificant in the lumpy zone.

Fluid flow fields for the three $\mathrm{CZ}$ treatments are compared in Figure 11. The results show that the gas velocity increases while gas passes through the coke window for the layered CZ treatment, and an intensive horizontal gas flow occurred through the identified $\mathrm{CZ}$ for the anisotropic nonlayered treatment. For all treatments, the solid flow direction evidently changed through the $\mathrm{CZ}$ because coke particles had to replace the space occupied by consumed ferrous materials, i.e., lumpy or agglomerated iron ores. Solid downward velocity in the lumpy zone was larger than that in the dripping zone because solid flow in the dripping zone was only driven by the coke consumption in the lower part of the BF. In addition, with the downward solid movement and coke consumption in the raceway, the deadman, i.e., the solid stagnant zone, clearly was

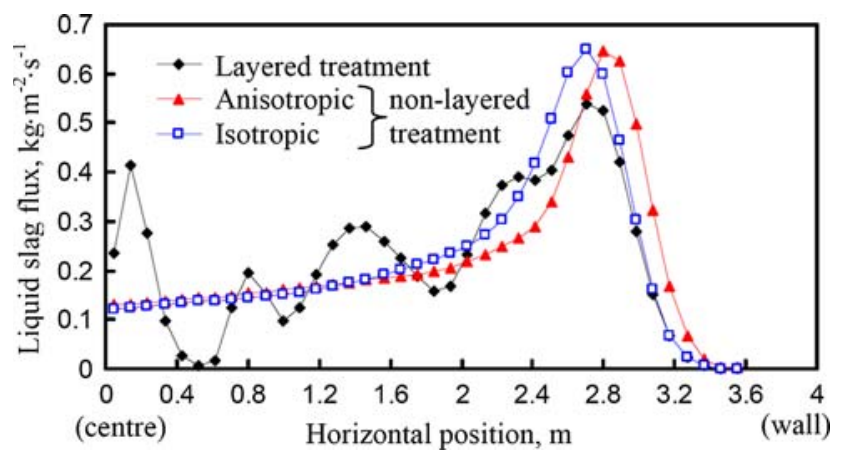

Fig. 12-Liquid slag flux distribution entering the hearth.

formed, in which permeability may deteriorate and small particles may accumulate.

As shown in Figure 11(g), from the molten region within the layered $\mathrm{CZ}$, generated liquids flowed almost vertically in the lower part of the furnace. However, complex localized liquid flows occurred in the $\mathrm{CZ}$ where some liquid droplets or rivulets were likely to flow along the layers. Similar phenomena were observed by Chew et al.$^{[17]}$ in a cold physical model describing liquid flow in which part of the dripping liquid preferentially accumulated in the lower layers of the CZ. This directly resulted in nonuniform liquid flow in the lower part of the furnace. Additionally, the internal structure of the lower part of the furnace made the nonuniform distribution of liquid flow more evident. In contrast, the liquid patterns generated by using nonlayered treatments showed relatively uniform liquid (volume fraction) distributions proportional to the ore-coke ratio in the $\mathrm{CZ}$.

For the layered treatment, the nonuniform liquid flow was demonstrated again by the horizontal distribution of liquid flux passing through the bottom of the simulation domain as shown in Figure 12. This liquid outlet represented the surface of the hearth where liquid collects in a BF. Liquid flux varied significantly along the horizontal direction, whereas a smooth distribution of liquid flux was observed for nonlayered treatments. The results also exhibited a maximum liquid slag flux located some distance from the tuyere for all three treatments. This behavior is believed to result from the combined contribution of the strong blast pushing liquid away from the tuyere and the high liquid flux trickling down from the lower, high ore volume fraction part of the CZ.

To examine the effect of different $\mathrm{CZ}$ treatments on heat and mass transfer, Figures 13-15 show the calculated phase temperature and $\mathrm{CO}$ concentration distributions. The results show that different temperature and concentration distributions were observed within and around the $\mathrm{CZ}$ for the different treatments. The effect of the different treatments on heat and mass transfer gradually decreased and became negligible at the furnace top, which indicates that the flow readjusted quickly in the lumpy zone so that the process variables were independent of the $\mathrm{CZ}$ treatments in the upper part of the furnace where the all cases had the same burden 
distribution. For all treatments, in the lumpy zone, the assumed charging pattern induced high permeability of the central part to achieve a central gas flow so that high gas temperatures and corresponding high solid temperatures were predicted near the furnace center as shown in Figures 13-15(a) and (b). At the upper-central part of the furnace, the $\mathrm{CO}$ concentration was high because of preferential gas flow and low ore to coke ratio.

However, the effect of these treatments on process variable profiles in the lower part of the $\mathrm{BF}$ was more

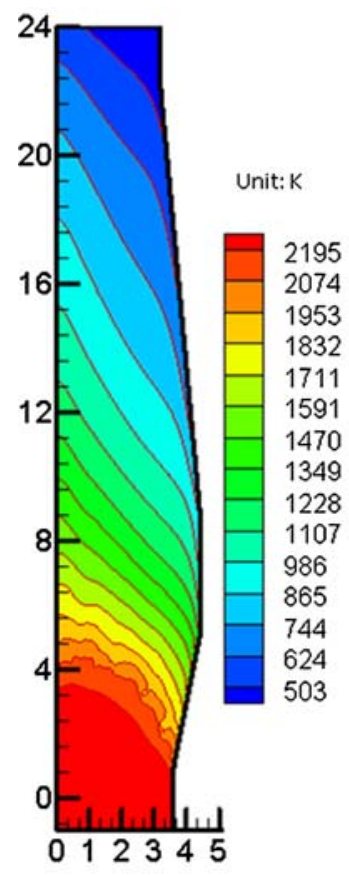

(a)

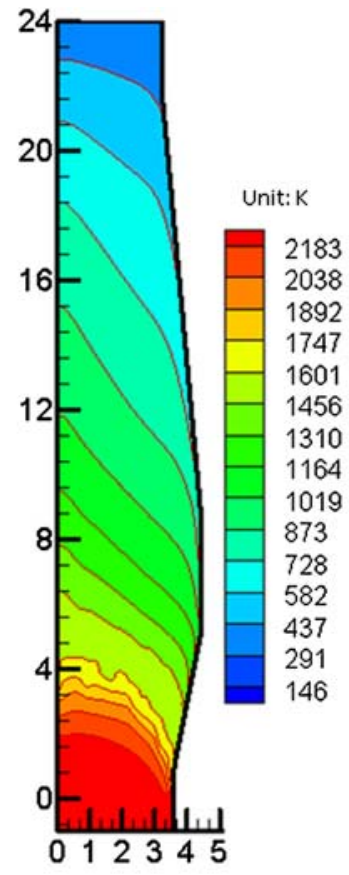

(b)

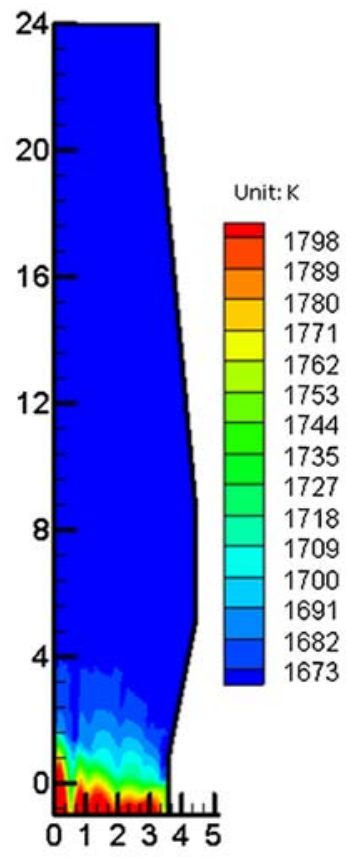

(c)

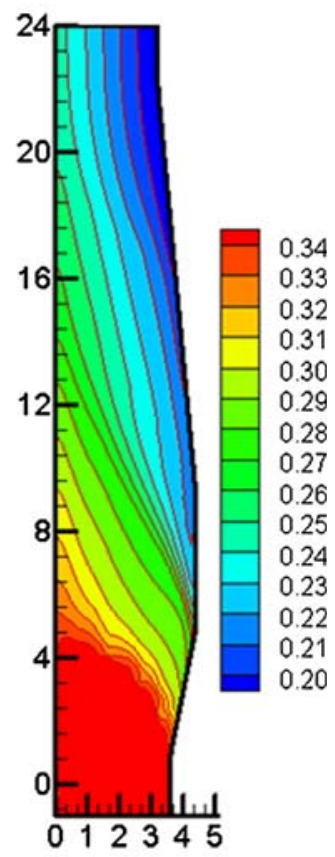

(d)

Fig. 13 - Computed contours of gas $(a)$, solid $(b)$, liquid $(c)$ temperature, and CO concentration $(d)$ for the layered treatment.

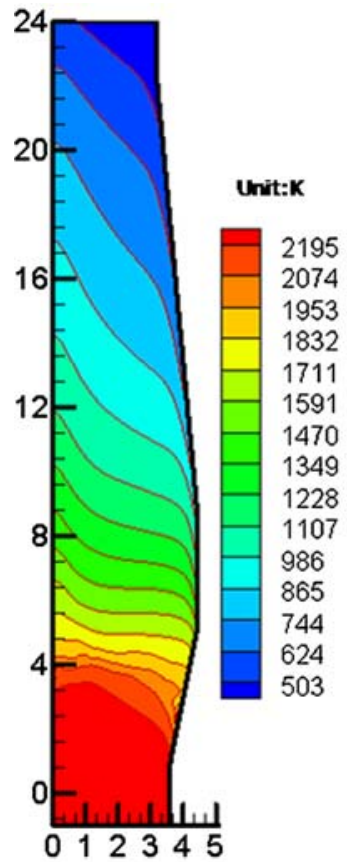

(a)

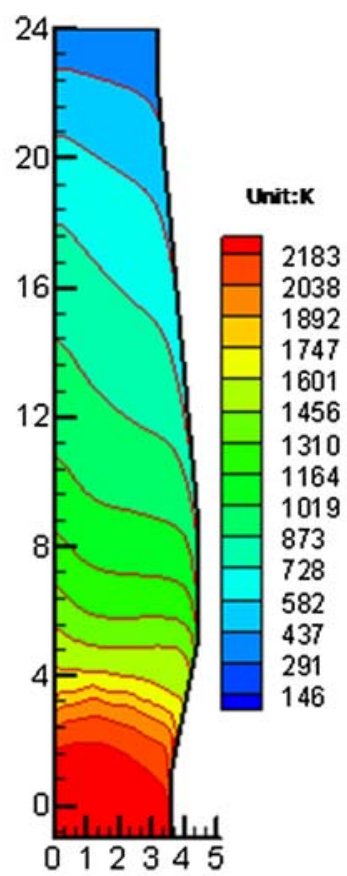

(b)

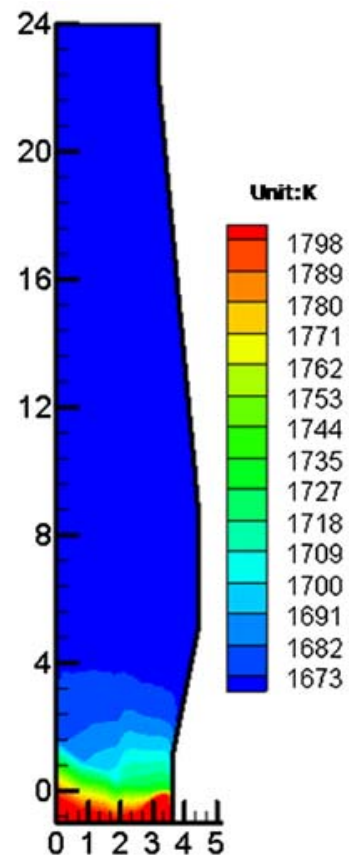

(c)

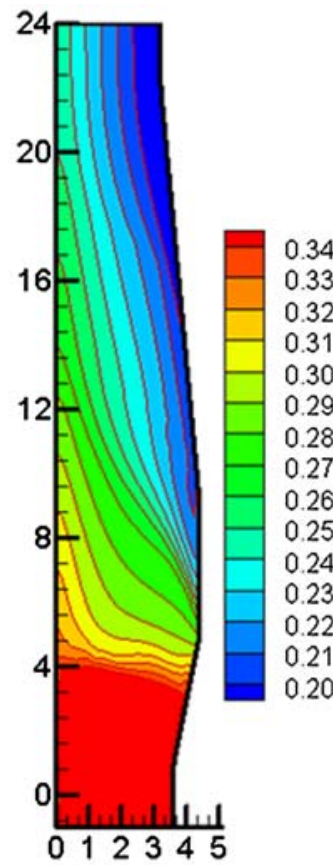

(d)

Fig. 14 Computed contours of gas $(a)$, solid $(b)$, liquid $(c)$ temperature, and CO concentration $(d)$ for anisotropic nonlayered treatment. 


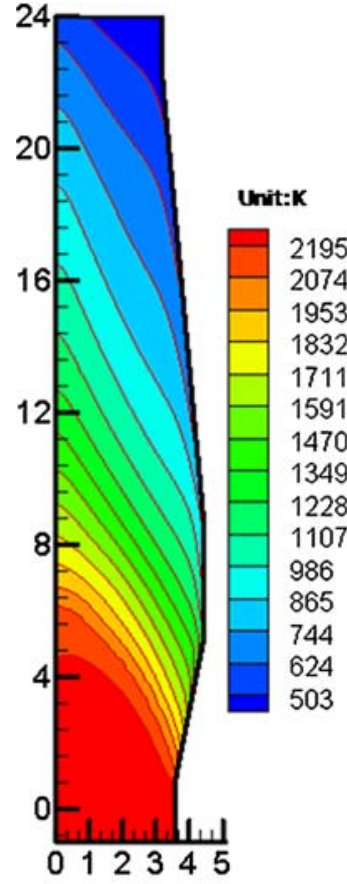

(a)

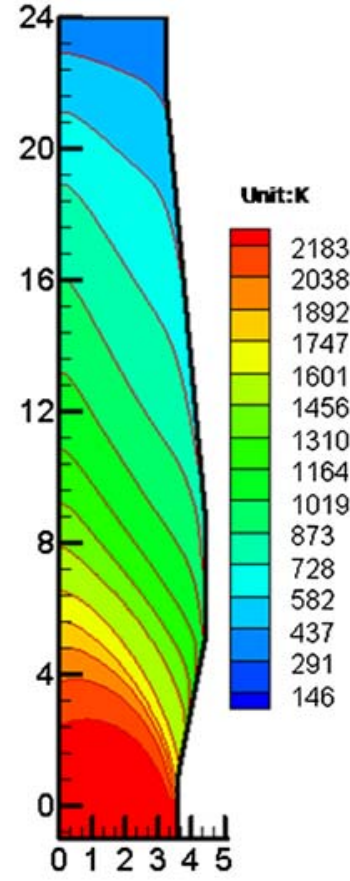

(b)

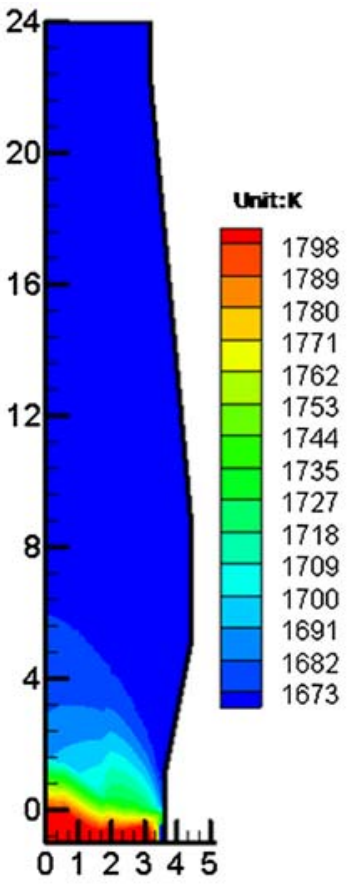

(c)

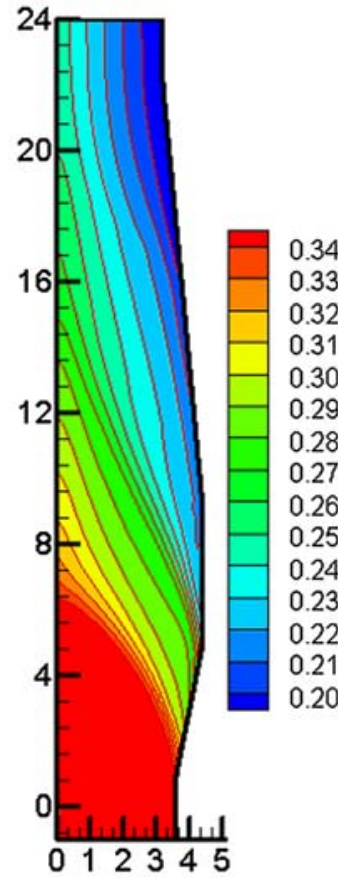

(d)

Fig. 15-Computed contours of gas $(a)$, solid $(b)$, liquid $(c)$ temperature, and CO concentration $(d)$ for isotropic nonlayered treatment.

evident, especially for the liquid temperature distribution, as shown in Figures 13-15(c). The difference in temperature distributions also is demonstrated in Figure 16. Liquid slag and hot metal temperatures not only were affected by the nonuniform gas and solid temperature distributions but also closely linked to the packing structure of the lower part of the BF. This finding was demonstrated by the liquid slag temperature gradient, which became larger within the deadman compared with that in the dripping zone. Similar to the liquid outlet flux distribution, liquid temperature fluctuated for the layered treatment, whereas the liquid temperature maintained a smooth variation for the isotropic and anisotropic nonlayered treatments.

When liquid flowed through the region adjacent to the tuyere, the strong heat exchange between gas and liquid made the liquid temperature abruptly increase for all three treatments. Apart from the region adjacent to the tuyere, a high-liquid temperature region was also observed in the central part of the furnace where liquid droplets experienced a longer trickling time from the $\mathrm{CZ}$ to the hearth because of the higher $\mathrm{CZ}$ position in the center than near the wall, and high solid temperatures in the deadman also play a role. This nonuniform temperature distribution made reactions between slag, coke, and gas more complex. It also implied that liquid properties were strongly dependent on the $\mathrm{CZ}$ structure because liquid residence time in the coke zone and deadman directly was related to the shape and position of the $\mathrm{CZ}$.

Different $C Z$ treatments represented different $B F$ operations and practice. For example, a layered $\mathrm{CZ}$ structure inevitably exists for BF operation with alternate

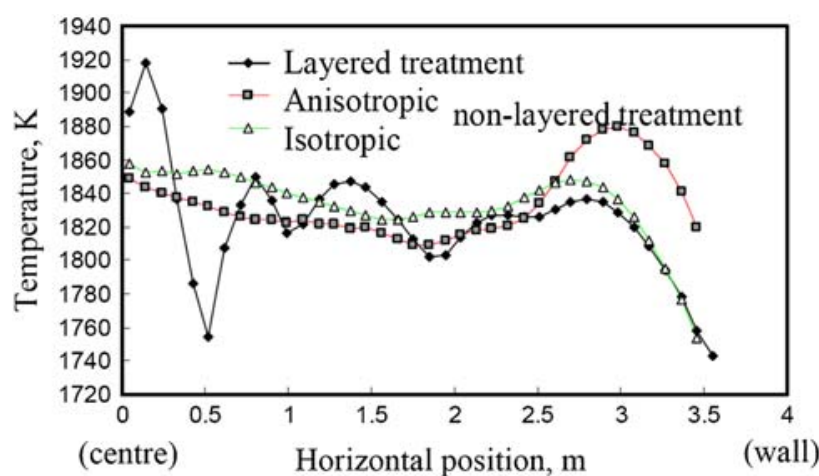

(a)

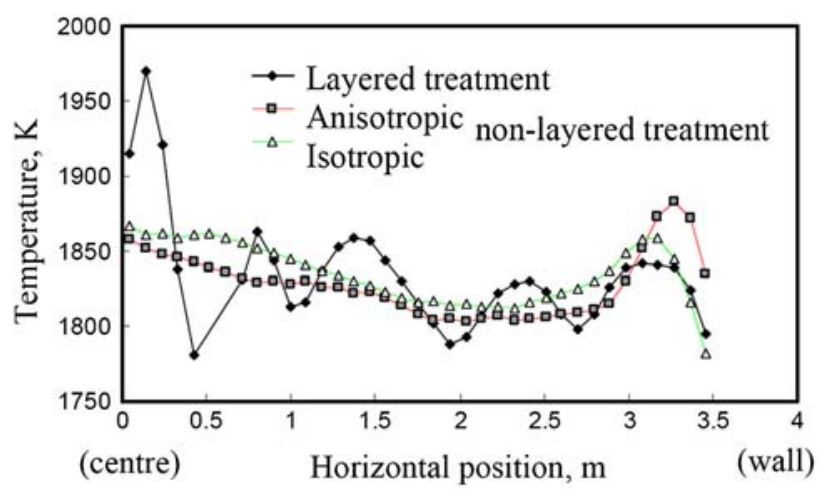

(b)

Fig. 16-Temperature distributions at the liquid outlet for (a) slag and $(b)$ hot metal. 
charging of iron-bearing materials and coke. Based on the previous results, the layered $\mathrm{CZ}$ treatment can predict the formation of coke windows and, therefore, reasonable $\mathrm{CZ}$ permeability, which largely reflects the BF situation. In contrast, for the anisotropic CZ treatment, the calculated axial resistance throughout the $\mathrm{CZ}$ region was high, which played an important role in generating horizontal gas flow in the CZ. When the batch weight of iron-bearing materials and coke was small, i.e., narrow layer distribution in the $\mathrm{BF}$, the calculated results using the anisotropic treatment could be similar to those using the layered treatment if the discrepancy in permeability between the two treatments could be eliminated. When the batch weight was large, the predicted pressure drop representing the fluid resistance in the $\mathrm{CZ}$ by the anisotropic $\mathrm{CZ}$ treatment could be higher than the real value because the role of the highly permeable coke layer was considered inadequately in the model formulation. In this case, the anisotropic CZ treatment should be adjusted for better permeability prediction. In the third approach, the isotropic nonlayered $\mathrm{CZ}$ treatment used the averaged properties of iron-bearing materials and coke to predict
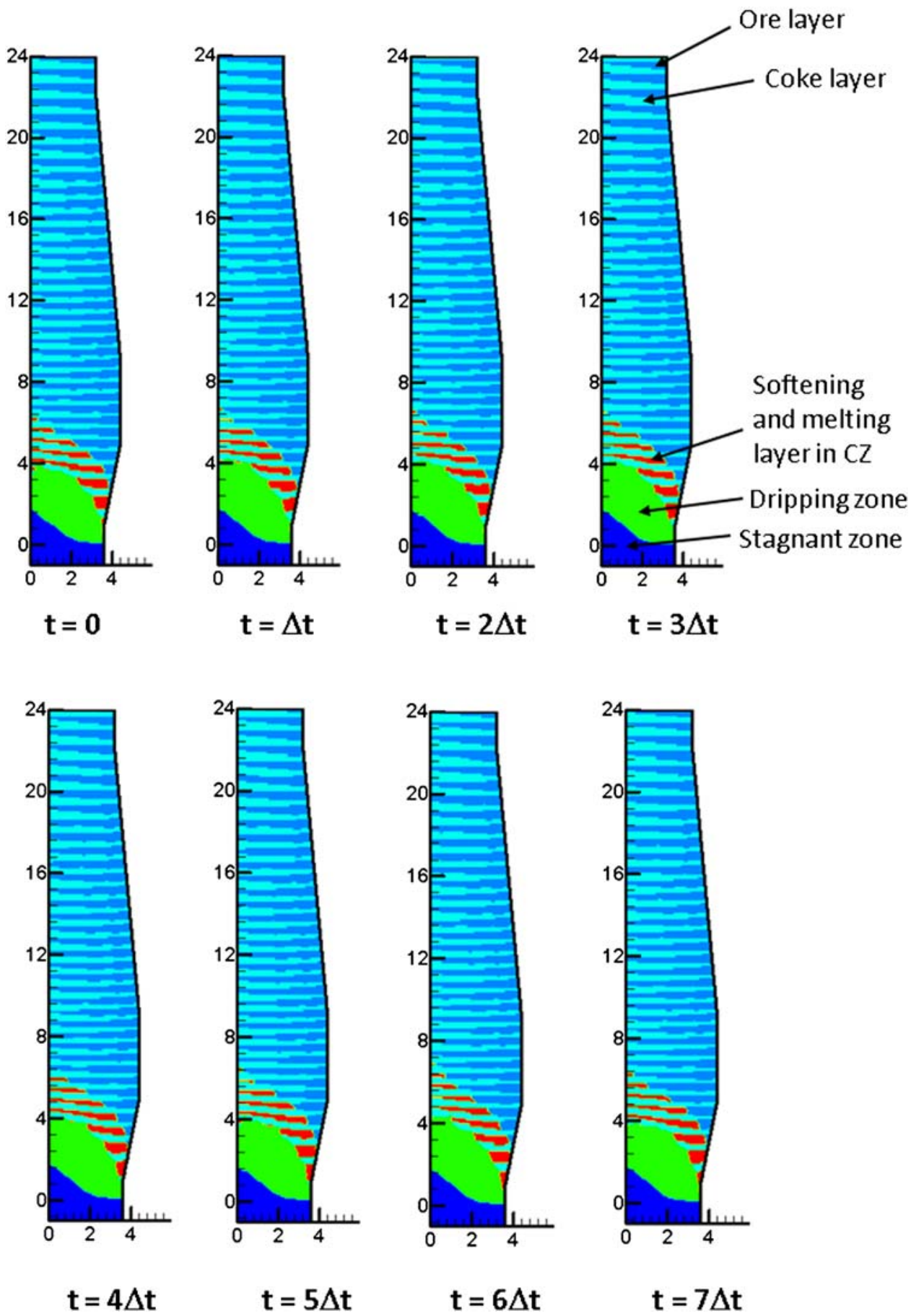

Fig. 17-Pseudo-transient process of solid flow $(\Delta \mathrm{t} \times 530 \mathrm{~s})$. 
the resistance, which weakened the effect of the low permeability region in the $\mathrm{CZ}$ on the fluid flow. From a practical viewpoint, this treatment is only suitable for modeling $\mathrm{BF}$ operation with mixed charging of ore and coke.

Finally, it should be noted that a BF is a moving bed reactor should be modeled as a transient process. A single-layered CZ configuration represented only a snapshot of this transient operation. However, different layer configurations could be used to model the burden positions at different times in the charging cycle as shown in Figure 17. Here, a total of eight burden distributions were used to represent a periodic burden flow. Corresponding to these different configurations, the layered CZ and process variable distributions could be calculated to produce average flow and performance variables. Because the residence time of gas and other phases is much shorter than that of solids in a BF for a given solid flow pattern, the gas and liquid flows, and to a large degree, temperature and concentration fields reasonably could be described as a steady-state process. Therefore, the distributions of the solid patterns and corresponding process variables represent a pseudotransient process.

Applying a simple averaging approach to the above pseudo-transient results in the following:

$$
\begin{aligned}
& \bar{\psi}=\frac{\sum_{\mathrm{i}}^{\mathrm{n}} w_{\mathrm{i}} \psi_{\mathrm{i}}}{\sum_{\mathrm{i}}^{\mathrm{n}} w_{\mathrm{i}}}, \\
& \psi=p, \varepsilon_{\mathrm{g}}, \varepsilon_{\mathrm{s}}, T_{\mathrm{g}}, T_{\mathrm{s}}, y_{\mathrm{co}}, \\
& w_{\mathrm{i}}=\frac{1}{n}, \quad n=8
\end{aligned}
$$

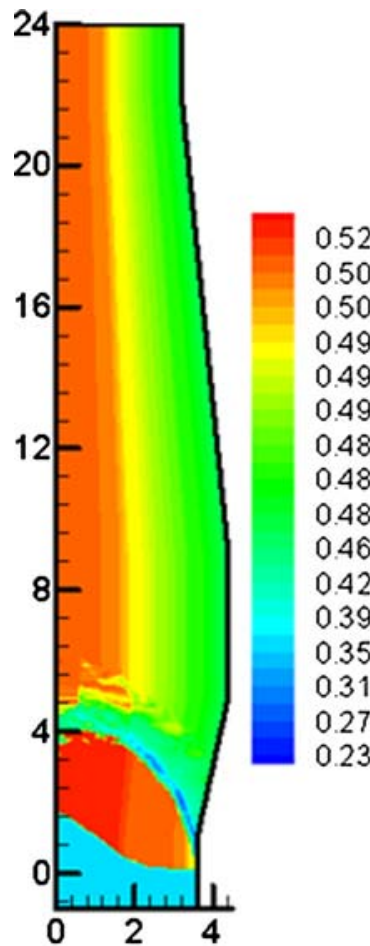

(a)

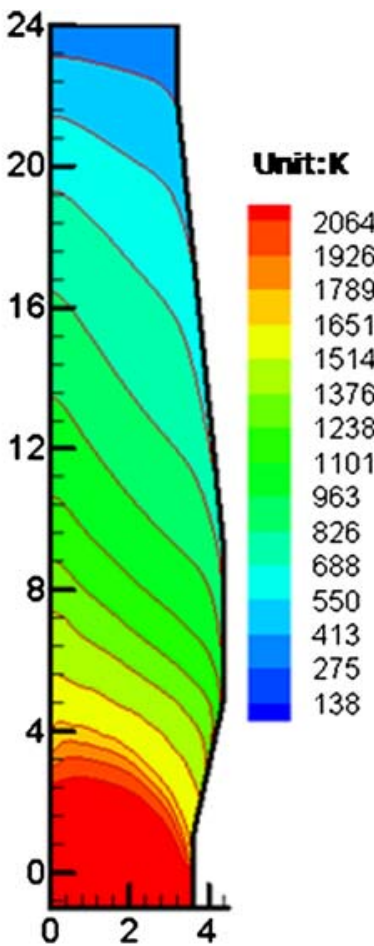

(b)

A selection of the averaged results are shown in Figure 18. The results show that an approximate porosity range from 0.23 to 0.5 could be obtained in the CZ. Based on the solid temperature, the averaged $\mathrm{CZ}$ is also shown in Figure 18(d). The CZ position predicted by the averaged results is different from that calculated with nonlayered CZ treatments (Figures 10(b) and (c)). Compared with the calculated results of the nonlayered CZ treatments, which may exaggerate the gas flow resistance or underestimate the flow variation in the CZ, the averaged results are based on more realistic permeability distributions and could better represent a steady $\mathrm{BF}$ operation. The application of different layer configurations to model a periodic burden flow provided an approach to better compare the layered CZ with the nonlayered $\mathrm{CZ}$ treatments and improved the applicability of the former to general $\mathrm{BF}$ simulation. Therefore, although obtained under steady-state conditions, the results predicted by the present approach were useful to process understanding.

\section{CONCLUSIONS}

A mathematical model was developed to describe the fluid flow, heat and mass transfer, as well as chemical reactions in a BF. Different from the previous models, the layered $\mathrm{CZ}$ was considered explicitly, and a critical comparison of $\mathrm{BF}$ modeling with different $\mathrm{CZ}$ treatments, i.e., layered, isotropic nonlayered, and anisotropic nonlayered, was carried out. The results showed that predicted fluid flow and thermochemical phenomena

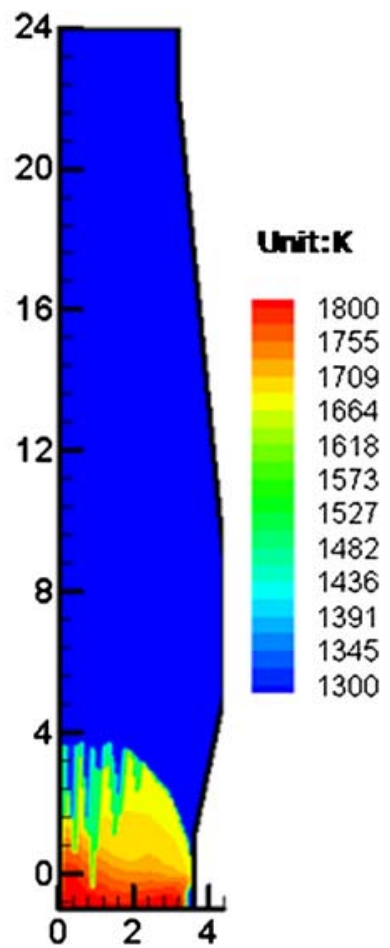

(c)

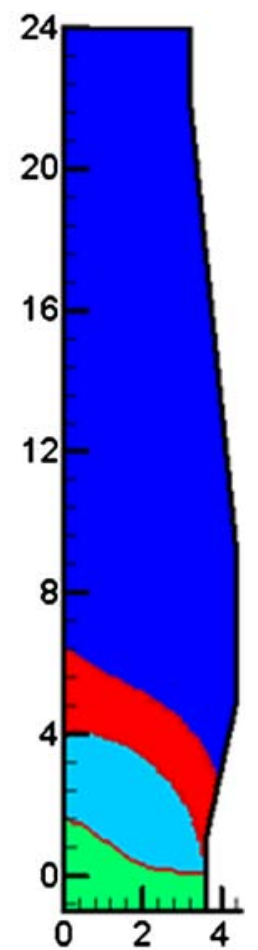

(d)

Fig. 18-Averaged process variable distributions for $(a)$ gas volume fraction, $(b)$ solid temperature, $(c)$ liquid temperature, and $(d) \mathrm{CZ}$ shape. 
within and around the $\mathrm{CZ}$ as well as in the lower part of the BF for different treatments were different. This finding implies that the $\mathrm{CZ}$ treatment is of paramount importance in $\mathrm{BF}$ modeling.

Physically, different $\mathrm{CZ}$ treatments may relate to different burden distributions at the furnace top. For example, the layered $\mathrm{CZ}$ treatment corresponded to the $\mathrm{BF}$ operation with layered charging of coke and ironbearing materials, the isotropic nonlayered treatment corresponded to the $\mathrm{BF}$ operation with the mixed charging of coke and iron-bearing materials, and the anisotropic nonlayered $\mathrm{CZ}$ treatment corresponded to the $\mathrm{BF}$ operation with layered charging but a small batch weight for coke and iron-bearing materials. From this point of view, BF modeling with a layered $\mathrm{CZ}$ treatment facilitated the simulation of conditions that could not be handled explicitly by a traditional BF model, such as the effects of charging sequence and batch weight. Moreover, by applying a range of layer configurations to achieve a pseudo-transient representation of $\mathrm{BF}$ operation, averaged results using a layered $\mathrm{CZ}$ treatment may provide a better overall picture of steady BF operation in terms of the permeability prediction when compared with the more common nonlayered $\mathrm{CZ}$ treatments. In this respect, a re-evaluation of the formulation that governs radial gas flow resistance in the anisotropic nonlayered CZ treatment would seem warranted. More studies are necessary to clarify these considerations and to extend this work to the simultaneous consideration of $\mathrm{BF}$ shaft, raceway, and hearth.

\section{ACKNOWLEDGMENTS}

The authors are grateful to the Australian Research Council and BlueScope Steel for the financial support of this work and to Professor J. Yagi at Tohoku University as well as Dr. P. R. Austin and Dr. D. Maldonado at BlueScope Steel Research for their valuable discussion.

\section{ABBREVIATIONS}

\section{$a, b \quad$ Coefficients in the Ergun equation,} $a=1.75, b=150$

$a_{\mathrm{FeO}} \quad$ The activity of molten wustite

$A_{c} \quad$ Effective surface area of coke for reaction, $\mathrm{m}^{2}$

$A_{\text {sl,d }} \quad$ Effective contact area between solid and

liquid in unit volume of bed, $\mathrm{m}^{2} \times \mathrm{m}^{-3}$

$\begin{array}{ll}c_{p} & \text { Specific heat, } \mathrm{J} \times \mathrm{kg}^{-1} \times \mathrm{K}^{-1} \\ d & \text { Diameter of solid particle, } \mathrm{m}\end{array}$

$d^{*} \quad$ Normalized particle size, $d^{*}=d / d_{\max }$

$d_{1, \mathrm{~g}} \quad$ Liquid droplet diameter as affected by gas flow, m

$d_{1, \mathrm{~h}} \quad$ Droplet diameter as affected by holdup, $\mathrm{m}$

$d_{\mathrm{w}} \quad$ Effective packing diameter, $\mathrm{m}$

$D \quad$ Diffusion coefficient, $\mathrm{m}^{2} \times \mathrm{s}^{-1}$

$D_{\mathrm{g}, \mathrm{n}}^{\mathrm{e}} \quad$ Effective diffusivity of component $n$, $n=C O, \mathrm{~m}^{2} \times \mathrm{s}^{-1}$

\begin{tabular}{|c|c|}
\hline$E_{\mathrm{f}}$ & $\begin{array}{l}\text { Effectiveness factors of solution loss } \\
\text { reaction }\end{array}$ \\
\hline$f_{0}$ & Fraction conversion of iron ore \\
\hline $\mathbf{F}$ & $\begin{array}{l}\text { Interaction force per unit volume, } \\
\mathrm{kg} \times \mathrm{m}^{-2} \times \mathrm{s}^{-2}\end{array}$ \\
\hline g & Gravitational acceleration, $\mathrm{m} \times \mathrm{s}^{-2}$ \\
\hline$h$ & Holdup \\
\hline$h_{1, \mathrm{t}}$ & Total holdup \\
\hline$h_{1, \mathrm{t} 0}$ & Total holdup without gas flow \\
\hline$h_{\mathrm{ij}}$ & $\begin{array}{l}\text { Heat transfer coefficient between } \mathrm{i} \text { and } \mathrm{j} \\
\text { phase, } \mathrm{W} \times \mathrm{m}^{-2} \times \mathrm{K}^{-1}\end{array}$ \\
\hline$H$ & Enthalpy, $\mathrm{J} \times \mathrm{kg}^{-1}$ \\
\hline$\Delta H$ & Reaction heat, $\mathrm{J} \times \mathrm{mol}^{-1}$ \\
\hline$k$ & Thermal conductivity, $\mathrm{W} \times \mathrm{m}^{-1} \times \mathrm{K}^{-1}$ \\
\hline$k_{\mathrm{f}}$ & $\begin{array}{l}\text { Gas-film mass transfer coefficient, } \\
\mathrm{m} \times \mathrm{s}^{-1}\end{array}$ \\
\hline $\mathrm{k}_{\mathrm{i}}$ & $\begin{array}{l}\text { Rate constant of ith chemical reactions } \\
(\mathrm{i}=1,2 \text {, or } 3), \mathrm{m} \times \mathrm{s}^{-1}\end{array}$ \\
\hline $\mathrm{K}_{1}$ & $\begin{array}{l}\text { Equilibrium constant of indirect reduction } \\
\text { of iron ore by } \mathrm{CO}\end{array}$ \\
\hline$M_{\mathrm{i}}$ & $\begin{array}{l}\text { Molar mass of ith species in gas phase, } \\
\mathrm{kg} \times \mathrm{mol}^{-1}\end{array}$ \\
\hline$M_{\mathrm{sm}}$ & $\begin{array}{l}\text { Molar mass of feo or flux in solid phase, } \\
\mathrm{kg} \times \mathrm{mol}^{-1}\end{array}$ \\
\hline$N u$ & Nusselt number, $\mathrm{Nu}=h \times d_{s} \times k^{-1}$ \\
\hline$p$ & Pressure, $\mathrm{Pa}$ \\
\hline$\Delta p_{e} / \Delta x$ & Effective pressure gradient, $\mathrm{Pa} \mathrm{m}^{-1}$ \\
\hline $\operatorname{Pr}$ & Prandtl number, $P r=c_{p} \times \mu \times k^{-1}$ \\
\hline $\mathrm{Re}_{g}$ & $\begin{array}{l}\text { Gas Reynolds number, } \\
\operatorname{Re}_{g}=\phi_{s} \times d_{s} \times \rho_{g} \times \varepsilon_{g} \times u_{g} \times \mu_{g}^{-1}\end{array}$ \\
\hline $\mathrm{R}$ & Gas constant, $8.314 \mathrm{~J} \times \mathrm{K}^{-1} \times \mathrm{mol}^{-1}$ \\
\hline$R^{*}$ & Reaction rate, $\mathrm{mol} \times \mathrm{m}^{-3} \times \mathrm{s}^{-1}$ \\
\hline$S$ & Source term \\
\hline$S h_{r}$ & $\begin{array}{l}\text { Shrinkage ratio defined as the ratio of the } \\
\text { decreased volume, caused by softening } \\
\text { and melting, to the original volume } \\
\text { occupied by iron-bearing materials }\end{array}$ \\
\hline$S h_{\mathrm{r}}^{*}$ & $\begin{array}{l}\text { Normalized shrinkage ratio, } \\
S h_{\mathrm{r}}^{*}=S h_{r} / S h_{r, \max }, S h_{r, \max }=0.7\end{array}$ \\
\hline$T$ & Temperature, $\mathrm{K}$ \\
\hline $\mathbf{u}$ & Interstitial velocity, $\mathrm{m} \times \mathrm{s}^{-1}$ \\
\hline$V_{\mathrm{b}}$ & Bed volume, $\mathrm{m}^{3}$ \\
\hline & Gas volume, $\mathrm{m}^{3}$ \\
\hline$V_{\text {ore, }} V_{\text {coke }}$ & Ore, coke volume, $\mathrm{m}^{3}$ \\
\hline$V o l_{\text {cell }}$ & Volume of control volume, $\mathrm{m}^{3}$ \\
\hline$X_{\mathrm{p}}$ & Dimensionless pressure drop \\
\hline$y_{\mathrm{i}}$ & Mole fraction of $i^{\text {th }}$ species in gas phase \\
\hline
\end{tabular}

\section{GREEK}

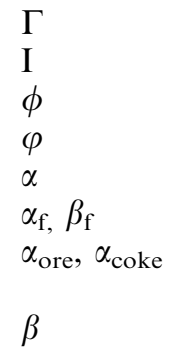

Diffusion coefficient

Identity tensor

General variable

Shape factor

Specific surface area, $\mathrm{m}^{-2} \times \mathrm{m}^{-3}$

Coefficients in Ergun Eq

Coefficients $\alpha_{\text {ore }}=a \varepsilon_{\text {ore }} / d_{\text {ore }}$,

$\alpha_{\text {coke }}=a \varepsilon_{\text {coke }} / d_{\text {coke }}$

Mass increase coefficient of fluid phase associated with reactions, $\mathrm{kg} \times \mathrm{mol}^{-1}$ 
$\beta_{\text {ore, }} \beta_{\text {coke }} \quad$ Coefficients, $\beta_{\text {ore }}=\frac{b \mu_{\mathrm{g}} \varepsilon_{\text {ore }}^{2}}{d_{\text {ore }}^{2}\left(1-\varepsilon_{\text {ore }}\right)}$,

$\beta_{\text {coke }}=\frac{b \mu_{\mathrm{g}} \varepsilon_{\text {coke }}^{2}}{d_{\text {coke }}^{2}\left(1-\varepsilon_{\text {coke }}\right)}$

$\gamma \quad$ Modification factor

$\delta \quad$ Distribution coefficient

$\varepsilon \quad$ Volume fraction

$\varepsilon^{*} \quad$ Normalized volume fraction, $\varepsilon^{*}=\varepsilon / \varepsilon_{\max }$

$\theta \quad$ Contact angle, degree

$\eta \quad$ Fractional acquisition of reaction heat

$\mu \quad$ Viscosity, $\mathrm{kg} \times \mathrm{m}^{-1} \times \mathrm{s}^{-1}$

$\rho \quad$ Density, $\mathrm{kg} \times \mathrm{m}^{-3}$

$\sigma \quad$ Surface tension, $\mathrm{N} \times \mathrm{m}^{-1}$

$\tau \quad$ Stress tensor, $\mathrm{Pa}$

$\omega \quad$ Mass fraction

$\xi_{\text {ore, }} \xi_{\text {coke }} \quad$ Local ore, coke volume fraction

\section{SUBSCRIPTS}

g

n

i

i, m

$\mathrm{j}$

$\mathrm{k}$

1

$1, \mathrm{~d}$

$\mathrm{s}$

sm

Effective

Gas

$\mathrm{N}$ direction $(=x$ or $y)$

Identifier (g, s or 1$)$

Mth species in $\mathrm{i}$ phase

Identifier (g, s or 1$)$

Kth reaction

Liquid

Dynamic liquid

Solid

Feo or flux in solid phase

\section{SUPERSCRIPTS}

$\begin{array}{ll}\mathrm{e} & \text { Effective } \\ \mathrm{g} & \text { Gas } \\ \mathrm{l}, \mathrm{d} & \text { Dynamic liquid } \\ \mathrm{s} & \text { Solid } \\ \mathrm{T} & \text { Transpose }\end{array}$

\section{REFERENCES}

1. Y. Omori: Blast Furnace Phenomena and Modelling, Elsevier, London, UK, 1987.

2. J. Yagi: ISIJ Int., 1993, vol. 33, pp. 619-39.

3. K. Takatani: Tetsu to Hagane, 1995, vol. 81, pp. 1031-35.

4. H. Nogami: Tetsu to Hagane, 2003, vol. 89, pp. 211-20.

5. X.F. Dong, A.B. Yu, J. Yagi, and P. Zulli: ISIJ Int., 2007, vol. 47, pp. 1553-70.

6. N. Busby, A. Fray, and D. Goldring: Ironmaking Steelmaking, 1994, vol. 21, pp. 229-36.

7. T. Bakker: Ph.D. Dissertation, Delft University of Technology, The Netherlands, 1999.

8. J. Sterneland and A. Lahiri: Ironmaking Steelmaking, 1999, vol. 26, p. 339

9. J. Mu, X. Bi, and G. Xi: Ironmaking Steelmaking, 1989, vol. 16, pp. $96-100$.

10. H. Gudenau and K. Kreibich: Scand. J. Metall., 1982, vol. 11, pp. 107-14.

11. T. Borinder and X. Bi: Scand. J. Metall., 1989, vol. 18, pp. 280-87.

12. P. Kaushik and R.J. Fruehan: Ironmaking Steelmaking, 2006 vol. 33, pp. 507-19.

13. P. Kaushik and R.J. Fruehan: Ironmaking Steelmaking, 2006, vol. 33 , pp. $520-28$.
14. S.H. Yi, W.W. Huh, C.H. Rhee, and B.R. Cho: Scand. J. Metall., 1999, vol. 28, pp. 260-65.

15. S. Story and R. Fruehan: Metall. Mater. Trans. B, 2000, vol. 31, pp. $43-54$

16. Y. Ohno and M. Schneider: Tetsu to Hagane, 1988, vol. 74, pp. 1923-30.

17. S.J. Chew, G.X. Wang, A.B. Yu, and P. Zulli: Ironmaking Steelmaking, 1997, vol. 24, pp. 392-400.

18. G.X. Wang, S.J. Chew, A.B. Yu, and P. Zulli: Metall. Mater. Trans. B, 1997, vol. 28, pp. 333-43.

19. X.F. Dong, D. Pinson, S.J. Zhang, A.B. Yu, and P. Zulli: Powder Technol., 2004, vol. 149, pp. 1-9.

20. S.J. Chew, P. Zulli, and A.B. Yu: ISIJ Int., 2003, vol. 43, pp. 304-13.

21. T. Sugiyama, J. Yagi, and Y. Omori: Proc. of 3rd Int. Iron and Steel Cong., 1978, pp. 479-88.

22. H. Gudenau, N. Standish, and W. Gerlach: Stahl und Eisen, 1992, vol. 8, pp. 73-79.

23. H. Gudenau, N. Standish, and W. Gerlach: Stahl und Eisen, 1992, vol. 9, pp. 113-19.

24. S.A. Zaimi, T. Buhles, G. Danloy, G. Dauwels, J.L. Eymond, G. Lesoin, and D. Sert, 4th ICSTI, 2006

25. S. Chew: Ph.D. Dissertation, University of New South Wales, Sydney, Australia, 1999.

26. J. Yagi, K. Takeda, and Y. Omori: ISIJ Int., 1982, vol. 22, pp. 884-92.

27. N. Nath: Mater. Manufactur. Processes, 2002, vol. 17, pp. 671-81.

28. G.X. Wang, J. Litster, and A.B. Yu: ISIJ Int., 2000, vol. 40, pp. $627-36$.

29. X.F. Dong, D. Pinson, S.J. Zhang, A.B. Yu, and P. Zulli: Appl. Math. Model., 2006, vol. 30, pp. 1293-309.

30. S.J. Zhang, A.B. Yu, P. Zulli, B. Wright, and P. Austin: Appl. Math. Model., 2002, vol. 26, pp. 141-54.

31. G.S. Gupta, J.D. Litster, V.R. Rudolph, E.T. White, and A. Domanti: ISIJ Int., 1996, vol. 36, pp. 32-39.

32. G.X. Wang, S.J. Chew, A.B. Yu, and P. Zulli: ISIJ Int., 1997, vol. 37 , pp. $573-82$.

33. S.A. Zaimi, D. Sert, G. Danloy, T. Buhles, G. Dauwels, J.L. Eymond, G. Lesoin, and T.R.N. Campos: ABM-Brazilian Association Metallurgy and Materials-XXXVIII Ironmaking and Raw Materials Seminar, 2007.

34. P.R. Austin, H. Nogami, and J. Yagi: ISIJ Int., 1997, vol. 37, pp. $458-67$.

35. S.J. Chew, P. Zulli, and A.B. Yu: ISIJ Int., 2001, vol. 41, pp. 1112 21.

36. I. Muchi: Trans. ISIJ, 1967, vol. 7, pp. 223-37.

37. X. Xiao, K. Nozawa, S. Sasahara, M. Shimizu, and S. Inaba: Tetsu to Hagane, 1992, vol. 78, pp. 1230-37.

38. P.R. Austin, H. Nogami, and J. Yagi: ISIJ Int., 1997, vol. 37, pp. $748-55$.

39. R.H. Perry and D.W. Green: Perry's Chemical Engineers' Handbook, 7th ed., pp. 14-38-14-48, McGraw-Hill, NY, 1997.

40. J. Beek: Adv. Chem. Eng., 1962, vol. 13, pp. 203-71.

41. D. Maldonado: Ph.D. Dissertation, University of New South Wales, Sydney, Australia, 2003.

42. M. Sasaki, K. Ono, A. Suzuki, Y. Okuno, and K. Yoshizawa: Trans. ISIJ, 1977, vol. 17, pp. 391-400.

43. K. Kanbara, M. Sasaki, Y. Okuno, and T. Katayama: 33rd Ironmaking Conf. Proc., Atlantic City, NJ, 1974, pp. 416-22.

44. T. Bakker and R.H. Heerema: 57th Ironmaking Conf. Proc., Toronto, Canada, 1998, pp. 1597-608.

45. CFD Flow Modeling Software and Solutions from Fluent, http:// www.fluent.com/, 2009.

46. ANSYS CFX, http://www.ansys.com/products/cfx.asp, 2009.

47. CD-adapco-CAE Flow Simulation software and services, http:// www.cd-adapco.com/products/STAR-CD/index.html, 2009.

48. M. Peric, R. Kessler, and G. Scheuerer: Comput. Fluids, 1988, vol. 16, pp. 389-403.

49. C.M. Rhie and W.L. Chow: AIAA J., 1983, vol. 21, pp. 1525-32.

50. S.V. Patankar: Numerical Heat Transfer and Fluid Flow, McGrawHill, NY, 1980.

51. H.L. Stone: SIAM J. Numer. Anal., 1968, vol. 5, pp. 530-58.

52. S.J. Zhang, A.B. Yu, P. Zulli, B. Wright, and U. Tuzun: ISIJ Int., 1998, vol. 38, pp. 1311-19.

53. S.J. Chew, P. Zulli, and A.B. Yu: ISIJ Int., 2001, vol. 41, pp. $1122-$ 30. 